\title{
Molecular diversity of the Fusarium fujikuroi species complex from maize
}

\author{
Emilia Jabłońska $(\mathbb{D} \cdot$ Krzysztof Piątek • Marcin Wit $\mathbb{D} \cdot$ \\ Ewa Mirzwa-Mróz $\mathbb{D}$ - Wojciech Wakuliński $(\mathbb{D}$
}

Accepted: 29 September 2020/Published online: 9 October 2020

(C) The Author(s) 2020

\begin{abstract}
Random amplified polymorphic DNA (RAPD) markers were used to estimate genetic relationship and diversity of Fusarium species associated with pink ear rot of maize. Three Fusarium species $F$. verticillioides, $F$. temperatum and $F$. subglutinans sensu stricto were collected from contaminated corn kernels. A collection of 41 randomly selected Fusarium isolates ( $16 F$. verticillioides, $16 F$. temperatum and nine $F$. subglutinans sensu stricto) was screened for polymorphism with thirty decamer primers. Seventeen primers that had generated a high number of polymorphic loci were used for the analysis of genetic diversity. The primers yielded a total of 146 polymorphic loci, an average of 8.59 polymorphic bands per primer. The percentage of polymorphic bands (\%P) was $46.1 \%$. The RAPD-based UPGMA analysis demonstrated that although $F$. temperatum and $F$. subglutinans s.s. form two distinct groups they are more similar to each other than to $F$. verticillioides. Fusarium verticillioides was the most heterogenous species (Nei's genetic diversity 0.180 ), while the least heterogenous one was $F$. subglutinans s.s. whose genetic diversity was 0.098 . The analysis of the translation elongation factor $1-\alpha$ and $\beta$-tubulin gene sequences as well as the mating type ratio were employed to support the RAPD data.
\end{abstract}

E. Jabłońska $(\bowtie) \cdot K$. Piątek $\cdot$ M. Wit $\cdot$ E. Mirzwa-Mróz $•$

W. Wakuliński

Department of Plant Protection, Institute of Horticultural Sciences, Warsaw University of Life Sciences, Warsaw, Poland

e-mail: emilia_jablonska@sggw.edu.pl
Keywords Fusarium fujikuroi species complex · Genetic diversity $\cdot$ Pink ear rot of maize $\cdot$ Random amplified polymorphic DNA

\section{Introduction}

Fusarium ear rot of maize, called also pink ear rot, is an economically important fungal disease commonly occurring in areas where maize is cultivated. The disease results in yield losses and the reduction of grain quality. A major economic threat is associated with this disease as Fusarium species possess the ability to synthesize mycotoxins in affected plants. The mycotoxins produced by these fungi are regarded as a potential threat to human and animal health (Voss et al. 2007; Desjardins 2006) and have a phytotoxic effect on plants as well (Lamprecht et al. 1994). The fumonisins are considered to be the most hazardous type due to their general toxicity and possible carcinogenicity to humans (Rheeder et al. 1992; IARC 1993). The occurrence of Fusarium ear rot - due to the prevalence, pathogenicity and toxigenic potential of its causative agents - is associated with significant economic losses in the world maize production (Logrieco and Visconti 2004; Wu 2007).

Fusarium ear rot is caused by several Fusarium species, including members of Fusarium fujikuroi species complex (FFSC). In maize-growing areas of Poland the predominant species are: F. temperatum and $F$. subglutinans sensu stricto, which are included in the so-called American clade according to O'Donnell et al. 
(1998b), and F. verticillioides - previously described as F. moniliforme (Seifert et al. 2003) - representing the African clade of the Fusarium fujikuroi species complex.

Fusarium temperatum and $F$. subglutinans sensu stricto are closely related species with a high level of morphological similarity. The number of septa and the shape of macroconidial basal cell are the morphological features that distinguish these two species (Scauflaire et al. 2011). Both species resemble a polyphyletic and cosmopolitan taxon, F. subglutinans sensu lato. A large number of cryptic species were described in the last two decades within $F$. subglutinans sensu lato. Besides $F$. temperatum and F. subglutinans s.s., this complex taxon includes species pathogenic to various plants, such as bananas $-F$. concentricum (Nirenberg and O'Donnell 1998), mangoes $-F$. mangiferae, $F$. sterilihyphosum (Britz et al. 2002) and $F$. mexicanum (Otero-Colina et al. 2010), sugarcanes $-F$. sacchari (Leslie et al. 2005) or pine trees $-F$. circinatum (Nirenberg and O'Donnell 1998; Britz et al. 1999). Originally isolated from maize, $F$. temperatum was described in 2011 by Scauflaire et al. as a distinct group within a collection of $F$. subglutinans strains. On the basis of the polyphasic approach proposed by Taylor et al. (2000) for species identification, $F$. temperatum can be distinguished from $F$. subglutinans s.s. mainly by the differences in their mycotoxin activity as well as translation elongation factor $1-\alpha$ (EF 1- $\alpha)$ and $\beta$-tubulin DNA sequences (Scauflaire et al. 2011).

Whereas $F$. temperatum and $F$. subglutinans sensu stricto have been found to date only on maize (Scauflaire et al. 2011), F. verticillioides is associated with a wide range of plant species. Beyond maize, $F$. verticillioides may infect rice, pineapples, sugarcane, sorghum, peas and fig trees (Nirenberg and O'Donnell 1998; O'Donnell et al. 1998b; Mułenko et al. 2008; Kvas et al. 2009; Hsuan et al. 2011; Stępień et al. 2013). The wide range of $F$. verticillioides host plants may be associated with the difficulty of defining clear species boundaries (Van Hove et al. 2011). With the implementation of new concepts of species definition, it has been shown that some known FFSC species characterized by a high level of genetic diversity consist of very similar twin taxa (Leslie 1995; Steenkamp et al. 2002; Kvas et al. 2009).

The purpose of this study was to assess the genetic diversity in the populations of Fusarium species associated with the pink ear rot of maize. For this purpose
RAPD markers were used. This technique has been reported to be suitable for assessing interspecific differences among Fusarium spp. strains collected from different hosts (Jiménez et al. 2000) and genetic variation within a population, e.g. in the case of Fusarium verticillioides strains (Kini et al. 2002).

\section{Materials and methods}

Fungal strains

Fusarium isolates were recovered from corn seeds obtained directly from naturally infected maize cobs with Fusarium ear rot symptoms, collected during four harvest seasons 2007-2010 in fields of central part of Poland, Radzików. Fusarium isolates were recovered from corn seeds with as well as without signs of Fusarium infection. After cob trashing, symptomatic corn kernels were directly plated on the synthetic nutrient agar (SNA), while healthy looking i.e. asymptomatic kernels were previously surface disinfected. Plates with 5 kernels on surface of agar medium were incubated in the light for 4-5 days at a room temperature. Identification of Fusarium sp. colonies was performed on the basis of morphological characters according to Nelson system of taxonomy (1983) and "The Fusarium Laboratory Manual" by Leslie and Summerell (2006). Single-spore Fusarium strains were obtained following the method described by Burgess and Liddell (1983). All strains were deposited in the Culture Collection of the Warsaw Agricultural University Herbarium (WAUF).

Most corn ear samples were collected from the single corn field of the Plant Breeding and Acclimatization Institute in Radzików, Poland (Mazowieckie province). Only in the case of $F$. subglutinans s.s. were isolates originating from other maize-growing areas outside Poland also included (Table 1).

\section{Molecular identification}

Single-spore strains mycelia grown for 5-7 days on potato dextrose agar (PDA) and then scraped off the surface of the media were used for the DNA extraction. Isolation of genomic DNA was achieved with the use of the modified CTAB method (Doohan et al. 1998; Tomczak et al. 2002). 
Table 1 Fusarium verticilioides, F. temperatum and F. subglutinans s.s. strains analysed in the study

\begin{tabular}{|c|c|c|c|c|c|}
\hline Species & Strain No. & Origin & MAT allele & EF $1-\alpha$ & $\beta$-tubulin \\
\hline \multirow[t]{16}{*}{ F. verticillioides } & KFI-633 & Poland & MAT1-1 & $\mathrm{n} / \mathrm{a}$ & $\mathrm{n} / \mathrm{a}$ \\
\hline & KFI-392 & Poland & MAT1-1 & $\mathrm{n} / \mathrm{a}$ & $\mathrm{n} / \mathrm{a}$ \\
\hline & KFI-522 & Poland & MAT1-1 & $\mathrm{n} / \mathrm{a}$ & $\mathrm{n} / \mathrm{a}$ \\
\hline & KFI-388 & Poland & MAT1-1 & $\mathrm{n} / \mathrm{a}$ & $\mathrm{n} / \mathrm{a}$ \\
\hline & KFI-622 & Poland & MAT1-2 & $\mathrm{n} / \mathrm{a}$ & $\mathrm{n} / \mathrm{a}$ \\
\hline & KFI-610 & Poland & MAT1-1 & $\mathrm{n} / \mathrm{a}$ & $\mathrm{n} / \mathrm{a}$ \\
\hline & KFI-680 & Poland & MAT1-2 & $\mathrm{n} / \mathrm{a}$ & $\mathrm{n} / \mathrm{a}$ \\
\hline & KFI-693 & Poland & MAT1-2 & $\mathrm{n} / \mathrm{a}$ & $\mathrm{n} / \mathrm{a}$ \\
\hline & KFI-694 & Poland & MAT1-2 & $\mathrm{n} / \mathrm{a}$ & $\mathrm{n} / \mathrm{a}$ \\
\hline & KFI-523 & Poland & MAT1-1 & $\mathrm{n} / \mathrm{a}$ & $\mathrm{n} / \mathrm{a}$ \\
\hline & KFI-373 & Poland & MAT1-2 & $\mathrm{n} / \mathrm{a}$ & $\mathrm{n} / \mathrm{a}$ \\
\hline & KFI-524 & Poland & MAT1-1 & $\mathrm{n} / \mathrm{a}$ & $\mathrm{n} / \mathrm{a}$ \\
\hline & KFI-525 & Poland & MAT1-1 & $\mathrm{n} / \mathrm{a}$ & $\mathrm{n} / \mathrm{a}$ \\
\hline & KFI-377 & Poland & MAT1-1 & $\mathrm{n} / \mathrm{a}$ & $\mathrm{n} / \mathrm{a}$ \\
\hline & KFI-445 & Poland & MAT1-2 & $\mathrm{n} / \mathrm{a}$ & $\mathrm{n} / \mathrm{a}$ \\
\hline & KFI-527 & Poland & MAT1-1 & $\mathrm{n} / \mathrm{a}$ & $\mathrm{n} / \mathrm{a}$ \\
\hline \multirow[t]{17}{*}{ F. temperatum } & KFI-612 & Poland & MAT1-2 & MT461303 & MT461329 \\
\hline & KFI-615 & Poland & MAT1-2 & MT461304 & MT461335 \\
\hline & KFI-617 & Poland & MAT1-1 & MT461305 & MT461336 \\
\hline & KFI-618 & Poland & MAT1-2 & MT461309 & MT461337 \\
\hline & KFI-620 & Poland & MAT1-2 & MT461312 & MT461338 \\
\hline & KFI-650 & Poland & MAT1-2 & MT461313 & MT461330 \\
\hline & KFI-653 & Poland & MAT1-1 & MT461311 & MT461331 \\
\hline & KFI-654 & Poland & MAT1-1 & MT461314 & MT461332 \\
\hline & KFI-655 & Poland & MAT1-1 & MT461308 & MT461333 \\
\hline & KFI-657 & Poland & MAT1-1 & MT461315 & MT461328 \\
\hline & KFI-662 & Poland & MAT1-1 & MT461306 & MT461339 \\
\hline & KFI-664 & Poland & MAT1-1 & MT461316 & MT461340 \\
\hline & KFI-690 & Poland & MAT1-2 & MT461318 & MT461334 \\
\hline & KFI-669 & Poland & MAT1-1 & MT461317 & MT461341 \\
\hline & KFI-687 & Poland & MAT1-1 & MT461310 & MT461342 \\
\hline & KFI-695 & Poland & MAT1-1 & MT461307 & MT461343 \\
\hline & KFI-607 & Poland & MAT1-1 & MT461327 & MT461352 \\
\hline \multirow[t]{8}{*}{ F. subglutinans s.s. } & KFI-717 & South Korea & MAT1-1 & MT461324 & MT461344 \\
\hline & KFI-719 & South Korea & MAT1-1 & MT461319 & MT461350 \\
\hline & KFI-720 & USA & MAT1-1 & MT461321 & MT461346 \\
\hline & KFI-722 & China & MAT1-1 & MT461326 & MT461349 \\
\hline & KFI-723 & China & MAT1-1 & MT461323 & MT461348 \\
\hline & KFI-718 & South Korea & MAT1-2 & MT461320 & MT461347 \\
\hline & KFI-721 & USA & MAT1-2 & MT461322 & MT461351 \\
\hline & KFI-724 & USA & MAT1-2 & MT461325 & MT461345 \\
\hline
\end{tabular}

n/a- not available 
Due to the high morphological similarity within FFSC, the final species identification was confirmed using molecular methods. Species-specific SCAR (Sequence Characterized Amplified Regions) markers (Mulè et al. 2004) were used for the initial identification of Fusarium verticillioides and $F$. subglutinans sensu lato. More detailed species identification was needed for $F$. subglutinans sensu lato species complex. According to numerous studies (O'Donnell et al. 1998a; Yli-Mattila et al. 2002; Harrow et al. 2010) the morphologically similar Fusarium species can be distinguished on the basis of the DNA sequence polymorphism in the translation elongation factor $1-\alpha(\mathrm{TEF} 1-\alpha)$ and $\beta$-tubulin gene. Whereas TEF1- $\alpha$ region is phylogenetically informative for most of the Fusarium species (Knutsen et al. 2004), additional sequence data from other genes is needed to differentiate $F$. temperatum from $F$. subglutinans sensu stricto and other closely related FFSC species (Geiser et al. 2004; Scauflaire et al. 2011). Therefore, the analysis was carried out on the basis of the DNA sequence data from both regions as described by O'Donnell et al. (1998b). The DNA sequences were amplified with the use of the primers developed by O'Donnell and Cigelnik (1997) and Geiser et al. (2004) respectively.

The PCR products were sequenced at the Institute of Biochemistry and Biophysics, Polish Academy of Science, Warsaw, Poland and assembled using DNA Baser Assembler v5.15 (Heracle BioSoft). The identification of each fungal strain was verified by the comparison of the obtained sequences with the data from NCBI GenBank (www.ncbi.nlm.nih.gov). The TEF1- $\alpha$ and $\beta$-tubulin partial gene sequences of $F$. temperatum and F. subglutinans s.s. were deposited in NCBI GenBank. The accession numbers for the sequences used in this study are provided in Table 1.

Mating types of the fungal strains were determined by a multiplex PCR assay according to thermal conditions described by Mohammadian et al. (2011), with the use of primers developed by Steenkamp et al. (2000) .

\section{RAPD assay}

For the purposes of the analysis 16 Polish strains of $F$. verticillioides and $F$. temperatum each were selected randomly from the obtained Fusarium population and reflected nearly equal frequency of these two species isolated from maize. Additionally nine strains of F. subglutinans s.s. were included to the studies. Due to the rare occurrence of this fungus only one isolate was of domestic origin and the additional eight isolates came from the areas outside Poland (Table 1).

Thirty RAPD primers (Operon Technologies) of recognized usefulness in the assessment of diversity within fungi of the Fusarium genus (El-Yazeed et al. 2011; Saharan 2010; Latiffah et al. 2008; Iqbal et al. 2006; Pamphile and Azevedo 2002; Viljoen et al. 1997) were used for this study. In the preliminary study selected primers were screened for reproducibility and polymorphism.

In order to ensure reproducible results, all of the amplifications were performed on only one thermal cycler, Veriti 96-Well Thermal Cycler (Applied Biosystems, USA). The reproducibility of the RAPD bands was found mainly by optimisation of PCR components and reaction conditions for the target species. Varying concentrations of selected RAPD primers, $\mathrm{MgCl}_{2}$ and template DNA were used in the preliminary analysis. Furthermore, following the results obtained by Skorić et al. (2012), the high concentration of Taq polymerase ( $3 \mathrm{U}$ in the $12 \mu \mathrm{l}$ reaction mixture volume) was used to provide the high intensity of the detectable bands.

As a result of previously performed gradient PCR with the temperature range of $34-40{ }^{\circ} \mathrm{C}$, the annealing temperature of $37^{\circ} \mathrm{C}$ was proved to be the most optimal for obtaining clear bands in RAPD patterns. Therefore, the amplification program was as follows: one cycle at $95^{\circ} \mathrm{C}$ for $1 \mathrm{~min}$ followed by 10 cycles at $94{ }^{\circ} \mathrm{C}$ for $5 \mathrm{~s}$, $37^{\circ} \mathrm{C}$ for $30 \mathrm{~s}, 72{ }^{\circ} \mathrm{C}$ for $30 \mathrm{~s}$ and 35 cycles with extended to $60 \mathrm{~s}$ elongation step $\left(94{ }^{\circ} \mathrm{C}\right.$ for $5 \mathrm{~s}, 37^{\circ} \mathrm{C}$ for $30 \mathrm{~s}, 72^{\circ} \mathrm{C}$ for $60 \mathrm{~s}$ ), finally one cycle at $72{ }^{\circ} \mathrm{C}$ for $7 \mathrm{~min}$.

At this stage of the research, in order to ensure that only reproducible bands are scored in the course of the analysis, a series of PCR reactions (in two replications) were conducted with selected primers (OPAC 19, OPAA 12) using previously established reagent concentrations and thermal cycling parameters. The obtained amplification profiles for both primers exhibited no differences.

Each $12 \mu \mathrm{l}$ reaction mixture consisted of $0.6 \mu \mathrm{l}$ of template DNA $(50 \mathrm{ng} / \mu \mathrm{l}), 1.2 \mu \mathrm{l}$ of RAPD primer $(10 \mu \mathrm{M} / \mu \mathrm{l}), 0.3 \mu \mathrm{l}$ of dNTPs, $0.06 \mu \mathrm{l}$ of Dream Taq DNA Polymerase (Thermo Fisher Scientific, USA) ( $5 \mathrm{U} / \mu \mathrm{l}), 0.9 \mu \mathrm{l}$ of $25 \mathrm{mM} \mathrm{MgCl}_{2}, 1.2 \mu \mathrm{l}$ of $10 \times \mathrm{PCR}$ buffer (Thermo Fisher Scientific, USA) and $7.74 \mu \mathrm{l}$ of sterile distilled water. 
The result of each amplification was visualized in $1.3 \%$ agarose gel (containing $0.1 \mathrm{mg} / \mathrm{ml}$ ethidium bromide) electrophoresis in $1 \times$ TBE (Tris-Borate Buffer). The agarose gel electrophoresis was performed using an Owl ${ }^{\mathrm{TM}}$ D4 Horizontal Electrophoresis System (Thermo Fisher Scientific, USA). The images of the banding patterns were acquired under UV light using a INGenius LHR2 gel imaging system (SynGene, UK).

\section{RAPD data analysis}

The amplification profiles were analysed in GeneTools 4.02.01 (Syngene, UK) and CLIQS 1D (TotalLab, UK). The size of RAPD PCR products was referenced to the GeneRuler 1 kb SM0313 DNA size marker (Thermo Fisher Scientific, USA). The number of all amplicons were counted and presented in the form of a binary matrix, which was prepared on the basis of the presence (" 1 ") or absence ("0") of specific bands.

The binary matrix combining the data records for all the 41 Fusarium isolates was analysed in programs: PopGene v.1.32 (Yeh et al. 1999), Past 3.14 (Hammer et al. 2001) and GeneAlEx 6.5 (Peakall and Smouse 2006, 2012).

The relevant parameters to be considered in order to estimate the efficiency of RAPD markers were:

- the total number of bands $\left(\mathrm{n}_{\mathrm{T}}\right)$ as well as the number of polymorphic $\left(n_{P}\right)$ and monomorphic bands $\left(n_{M}\right)$;

- the percentage of polymorphic bands for all assays $(\% \mathrm{P})$ and per single assay unit $\left(\mathrm{n}_{\mathrm{P}} / \mathrm{U}\right)$,

- polymorphism information content (PIC) according to the formula of De Riek et al. (2001) for dominant markers:

PIC $=1-\left[p^{2}+(1-p)^{2}\right]$, where' $p^{\prime}$ is thefrequency of the maker

- resolving power (RP) and mean resolving power (MRP) according to Prevost and Wilkinson (1999):

$$
R P=\sum B I, \quad M R P=1 / n \sum_{1} B I_{i},
$$

where 'BI' is band informativeness calculated as $\mathrm{BI}=1$ $-[2 \times(0.5-\mathrm{p})]$.

and where ' $p$ ' is the proportion of individuals containing the band;

- effective multiplex ratio (EMR) according to Powell et al. (1996) formula:

$$
E M R=\% P \times n U
$$

- marker index (MI) according to Powell et al. (1996) formula:

$$
M I=P I C \times E M R .
$$

In order to determine the diversity within and among the surveyed Fusarium species the following diversity indices were calculated with the use of PopGene software version 1.32 (Yeh et al. 1999) and GenAlEx 6.5 (Peakall and Smouse 2006, 2012):

- gene diversity (h) according to Nei (1973): $h=1-$ $\left(p^{2}+q^{2}\right)$, where ' $p$ ' is the frequency of the RAPD band and $\mathrm{q}=1-\mathrm{p}$;

- coefficient of genetic differentiation $\left(\mathrm{G}_{\mathrm{ST}}\right)$, which was estimated on the basis of the value of total genetic diversity $\left(\mathrm{H}_{\mathrm{T}}\right)$ and genetic diversity within populations $\left(\mathrm{H}_{\mathrm{S}}\right)$ according to Nei (1973):

$$
\mathrm{G}_{\mathrm{ST}}=\frac{\mathrm{H}_{\mathrm{T}}-\mathrm{H}_{\mathrm{S}}}{\mathrm{H}_{\mathrm{T}}}
$$

- Shannon-Weaver diversity index (I) according to the formula of Shannon and Weaver (1949):

$I_{s w}=-1 \times[p \times \ln (p)+q \times \ln (q)]$,

where' $p$ ' is the frequency of the RAPD band and $q=1-p$,

- the number of migrants per generation $\left(\mathrm{N}_{\mathrm{m}}\right)$ which is regarded as indirect estimation of the amount of gene flow between populations was calculated by the formula of McDermott and McDonald (1993):

$N_{m}=0.5\left(1-G_{S T}\right) / G_{S T}$.

In addition, genetic similarity (GS) was estimated among all the 41 tested Fusarium strains. Calculations were based on four similarity coefficients: Jaccard (1908); Kulczyński (1927); Dice (1945) - estimated with the formula of Nei and Li (1979) - and Ochiai (1957). Correlation coefficients between the GS values 
obtained with the use of various measures were determined with the significance level of $\alpha=0.001$.

The obtained similarity index matrices were subsequently used for the cluster analysis in Past 3.14 (Hammer et al. 2001). With the use of principal coordinate analysis (PCoA) and the unweighted pair group method with arithmetic mean (UPGMA), the genetic relatedness of all the 41 tested Fusarium strains was shown on graphs and dendrograms, respectively.

For separate species, the phylogenetic network analyses was performed with SplitsTree 4.16.0 using the NeighborNet algorithm (Huson and Bryant 2006). To verify the presence of recombination, the PHI (Pairwise Homoplasy Index) test (Bruen et al. 2006) was performed.

Nucleotide sequence analysis

For the purpose of analysis, the obtained sequences of the translation elongation factor $1-\alpha$ and $\beta$-tubulin gene were visually inspected using Chromas 2.6.6 (Technelysium, Australia) and then aligned with the ClustalW algorithm implemented in MEGA 7.0.6 (Kumar et al. 2016). The low-quality read and alignment-ambiguous regions were excluded from subsequent analyses.

The genetic diversity analysis was conducted on all of the obtained sequences as well as on their concatenations. The nucleotide diversity, the GC content, the number of segregating sites and estimates of Theta $(\Theta)$ per site were determined using the DnaSP 5.10.01 (Rozas et al. 2009). The same software was used to perform Tajima's Neutrality Test (Tajima 1989).

The phylogenetic analysis was performed with the use of maximum likelihood (ML) method with 1000 bootstrap replicates and visualised with MEGA 7.0.6. F.verticillioides strain 7600 (Sequence ID: NC_031676.1) was used as outgroup.

\section{Results}

The effectiveness of the selected RAPD primers

Out of the 30 pre-analysed oligonucleotide RAPD primers (Operon Technologies, USA), the 17 primers (Table 2) generating clear, stable amplification profiles with a large number of bands were finally selected for this study. Thirteen remaining primers were discarded due to the insufficient number of generated amplicons (OPAC 03, OPAC 12, OPAD 04, OPAD 05, OPC 02) or the total lack of amplification products (OPAA 16, OPAA 17, OPAD 15, OPP 03, OPX 02, OPX 12, OPX 14, OPX 18).

A total of 317 amplification products were generated with the use of the 17 selected RAPD primers with 41 Fusarium spp. strains. The band sizes ranged from 105 to $3134 \mathrm{bp}$. The number of products generated by a single decamer RAPD primer was found to range from 9 - with primer OPAC 17 - up to 27 bands with primers OPX 07 and OPX 09 (Table 2).

The RAPD markers selected for the analysis proved to be effective in discriminating the 41 Fusarium strains. Nearly half of the generated loci $(46.1 \%)$ were polymorphic. The frequencies of polymorphic bands ranged from $34.0 \%$ (primer OPAD 10) to $68.3 \%$ (OPAD 12). The highest frequency of polymorphic bands that exceeded $60 \%$ was noted when OPAA 09 , OPAA 12 (Fig. 1), OPAD 12 and OPX 15 primers were used (Table 2).

On average, 18.65 products were obtained in a single PCR reaction with one primer. The effectiveness of the RAPD technique, expressed by the average number of polymorphic bands per reaction, was 8.59 (Table 2).

While according to De Riek et al. (2001) the maximum value of polymorphism information content (PIC) for dominant markers such as RAPD is 0.5 , the average PIC in this study was 0.261 . The PIC value ranged from 0.215 (OPAA 13) to 0.315 (OPX 15). Apart from few markers indicating PIC values below 0.25 (OPAA 13, OPAC 17, OPAC 10, OPAD 10, OPAC 19, OPX 01), most of the markers used in the study were polymorphic and informative, out of which three markers (OPAC 11, OPL 15 and OPX 15) could be regarded as - according to Botstein et al. (1980) - highly informative ones with PIC value of greater than 0.3 .

The average resolving power of primers (RP) in this study was 5.69 ranging from 2.63 (OPAC 17) to 8.35 (OPL 15), while mean resolving power (MRP) varied from 0.29 (OPAC 17) to 0.45 (OPL 15, OPX 15) with mean value of 0.37 . Although primer OPL 15 showed the highest noted RP, MRP and PIC values, the percentage of polymorphic bands generated with this primer was one of the lowest among all tested markers (39.5\%).

As indicated by the marker index (MI) combining the values of PIC and EMR, the two primers that were proven to be the most effective in differentiation of analysed Fusarium species were OPAA 09 and OPAD 12. Both primers were characterized by the highest MI value of 2.75 , while the average MI value in this study 
Table 2 Parameters of RAPD primers used in the study

\begin{tabular}{|c|c|c|c|c|c|c|c|c|c|c|c|}
\hline Primer & Sequence $\left(5^{\prime}-3^{\prime}\right)$ & $\mathrm{n}_{\mathrm{T}}$ & $\mathrm{n}_{\mathrm{p}}$ & $\mathrm{n}_{\mathrm{M}}$ & $\mathrm{n}_{\mathrm{P}} / \mathrm{U}(\%)$ & Bands size range (bp) & $\mathrm{PIC}$ & $\mathrm{RP}$ & MRP & EMR & MI \\
\hline OPAA 09 & AGATGGGCAG & 20 & 12 & 8 & 62.1 & $116-2271$ & 0.257 & 5.98 & 0.36 & 10.70 & 2.75 \\
\hline OPAA 12 & GGACCTCTTG & 14 & 9 & 5 & 64.7 & $221-2620$ & 0.253 & 4.08 & 0.34 & 8.12 & 2.06 \\
\hline OPAA 13 & GAGCGTCGCT & 17 & 8 & 9 & 49.3 & 205-2217 & 0.215 & 5.00 & 0.31 & 8.07 & 1.73 \\
\hline OPAC 10 & AGCAGCGAGG & 22 & 8 & 14 & 34.9 & $105-1764$ & 0.225 & 5.91 & 0.31 & 7.18 & 1.61 \\
\hline OPAC 11 & CCTGGGTCAG & 17 & 7 & 10 & 38.5 & $177-2505$ & 0.303 & 6.04 & 0.44 & 5.81 & 1.76 \\
\hline OPAC 17 & CCTGGAGCTT & 9 & 5 & 4 & 56.4 & $345-2562$ & 0.224 & 2.63 & 0.29 & 5.08 & 1.14 \\
\hline OPAC 19 & AGTCCGCCTG & 18 & 9 & 9 & 50.0 & $194-2166$ & 0.231 & 4.50 & 0.32 & 7.41 & 1.71 \\
\hline OPAD 10 & AAGAGGCCAG & 26 & 9 & 17 & 34.0 & $181-2406$ & 0.226 & 6.03 & 0.30 & 7.41 & 1.68 \\
\hline OPAD 12 & AAGAGGGCGT & 16 & 11 & 5 & 68.3 & $107-2731$ & 0.277 & 5.55 & 0.39 & 9.92 & 2.75 \\
\hline OPF 01 & ACGGATCCTG & 18 & 7 & 11 & 36.9 & 199-3134 & 0.281 & 6.54 & 0.42 & 6.16 & 1.73 \\
\hline OPL 15 & AAGAGAGGGG & 23 & 9 & 14 & 39.5 & $187-2603$ & 0.306 & 8.35 & 0.45 & 7.93 & 2.43 \\
\hline OPX 01 & CTGGGCACGA & 10 & 6 & 4 & 57.6 & $350-2202$ & 0.243 & 3.20 & 0.35 & 5.33 & 1.29 \\
\hline OPX 06 & ACGCCAGAGG & 21 & 9 & 12 & 42.1 & 199-2352 & 0.287 & 7.20 & 0.41 & 7.82 & 2.25 \\
\hline OPX 07 & GAGCGAGGCT & 27 & 12 & 15 & 42.8 & $163-2294$ & 0.257 & 8.01 & 0.36 & 10.27 & 2.64 \\
\hline OPX 09 & GGTCTGGTTG & 27 & 10 & 17 & 37.1 & $130-2659$ & 0.279 & 7.84 & 0.42 & 7.92 & 2.21 \\
\hline OPX 15 & CAGACAAGCC & 14 & 9 & 5 & 66.7 & 211-1908 & 0.315 & 4.46 & 0.45 & 7.02 & 2.21 \\
\hline OPX 17 & GACACGGACC & 18 & 6 & 12 & 35.2 & $137-2409$ & 0.262 & 5.39 & 0.36 & 5.50 & 1.44 \\
\hline Total & & 317 & 146 & 171 & & & & & & & \\
\hline \multicolumn{2}{|c|}{ Average per primer } & 18.65 & 8.59 & 10.06 & 46.1 & & 0.261 & 5.69 & 0.37 & 7.51 & 1.96 \\
\hline
\end{tabular}

$n T$, total number of generated bands; $n P$, number of polymorphic bands; $n M$, number of monomorphic bands; $n P / U:$ percentage of polymorphic band per reaction; $P I C$ : polymorphism information content; $R P$ : resolving power; $M R P$ : mean resolving power; $E M R$ : effective multiplex ratio; $M I$ : marker index

Fig. 1 RAPD profile of

Fusarium spp. produced with primer OPAA 12. Lane M is $1 \mathrm{~kb}$ DNA ladder, lanes 1-16 represent strains of $F$. verticillioides, $17-$ 32: F. temperatum, 33-41:

F. subglutinans s.s

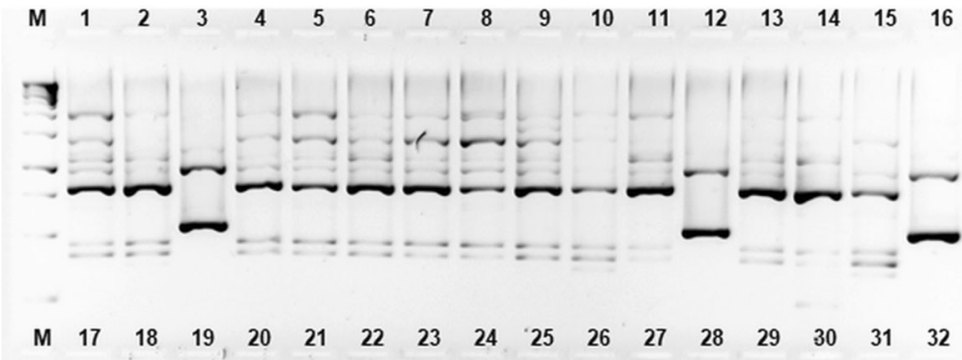

r7
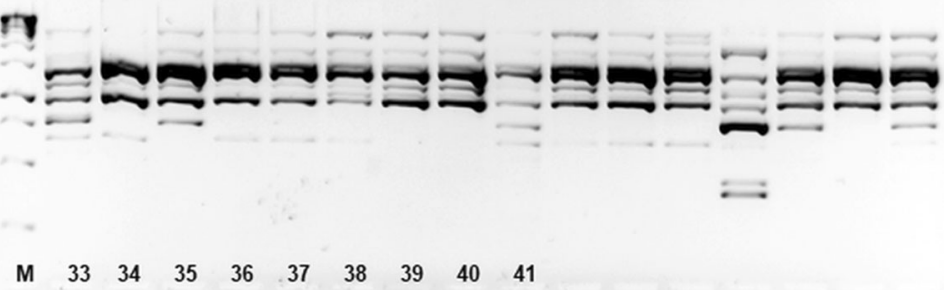

9

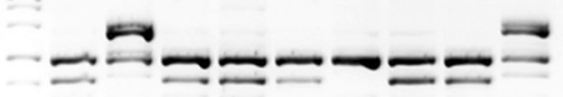


was 1.96 with the minimum 1.14 noted for OPAC 17. The highest efficiency of OPAA 09 and OPAD 12 - as diversity markers in this study - was confirmed by other coefficients such as effective multiplex ratio (10.70; 9.92) and the high percentage of polymorphic loci $(62.1 \% ; 68.3 \%)$ (Table 2).

Genetic diversity within populations

Despite the high proportion of polymorphic bands $(46.1 \%)$ observed in the amplification profiles (Table 2), the genetic diversity within the analysed population of Fusarium spp. was rather moderate, as evidenced by the value of Shannon-Weaver index (0.467) (Table 3).

A comparison of this index among the three analysed species revealed that the Shannon-Weaver index was lowest in the $F$. subglutinans sensu stricto (0.148) and highest in the $F$. verticillioides $(0.275)$. The same trend was observed for the Nei's genetic diversity which varied from 0.098 (F. subglutinans s.s.) to 0.180 (F. verticillioides), with an average of 0.303 (Table 3 ). The linear relationship between the observed genetic diversity of the analysed species and their polymorphism is presented graphically in Fig. 2.

The $\mathrm{G}_{\mathrm{ST}}$ value of 0.552 indicated a relatively high level of population differentiation (Table 3 ). The lowest interpopulation diversity was noted between $F$. temperatum and $F$. subglutinans sensu stricto (0.472). The populations of these two closely related, almost morphologically identical species were characterized by the highest gene flow recorded in the study (0.515). Within the entire sample, the gene flow reached 0.406 (Table 3) and varied from 0.448 to 0.515 (Table 4). Such low level of gene flow seems to be consistent with the observed large genetic diversity noted between the analysed species of $F$. verticillioides, $F$. temperatum and $F$. subglutinans sensu stricto. These results are also confirmed by the conducted analysis of molecular variance (AMOVA), which revealed that a very high variation occurred between species (61\%), whilst only $39 \%$ occurred among species.

Phylogenetic relationship between Fusarium strains

The mean genetic similarity (GS) among the analysed Fusarium strains varied from 0.312 (according to Jaccard's similarity coefficient) to 0.441 (Kulczyński's coefficient) (Table 5). In general, the correlation between similarity coefficients was very high, exceeding more than 0.99 , whilst the lowest correlation with other measures was shown by the Jaccard coefficient (0.99661-0.99667; Table 6). The genetic similarity matrix identified according to this coefficient varied from 0.103 to 0.896 (Table 5).

The most consistent classifications of isolates were obtained with the Dice, Kulczyński and Ochiai similarity coefficients. The genetic similarity calculated with these coefficients ranged from 0.186 (according to Dice and Ochiai) and 0.187 (Kulczyński) to 0.945 (for all three coefficients) (Table 5). These three coefficients were very strongly positively correlated $(r>0.99998)$ at the significance level of 0.001 (Table 6).

At the species level, the highest genetic similarity was noted within $F$. subglutinans s.s. $(0.762)$ with only $7.79 \%$ variability. The genetic similarities within strains of this species ranged from 0.616 to 0.876 . On the contrary, $F$. verticillioides proved to be the most diverse one with the highest coefficient of similarity variation $(31.25 \%)$. The genetic similarities among $F$. verticillioides isolates ranged from 0.302 to 0.862 (according to the mean value of the four similarity coefficients used) (Table 7).

On the basis of the similarity matrices generated with the use of Dice's, Jaccard's, Kulczyński's and Ochiai's coefficients, the UPGMA cluster analysis was carried out. The resulting dendrograms are shown in Fig. 3. The analysis divided the analysed Fusarium strains into two distinct clusters. Interestingly, F. temperatum and F.subglutinans s.s. strains were grouped together in one cluster. Strains representing these two species were the most similar (0.732) (Table 8). The second, most separated cluster was a group of 16 F.verticillioides strains. The dendrograms reflect the large genetic distance separating strains of F.verticillioides from the $F$. temperatum and $F$. subglutinans sensu stricto strains which proved to be consistent with their taxonomic classification (Fig. 3). The largest genetic distance was recorded between $F$. verticillioides and $F$. subglutinans s.s. strains (0.359) (Table 8). The results of the UPGMA cluster analysis prepared on the basis of the similarity matrices by Dice (Fig. 3a), Kulczyński (Fig. 3c) and Ochiai (Fig. 3d) show almost identical topology. The only slight difference in topology was noted within the $F$. verticillioides. On the dendrograms generated according to Dice, Jaccard and Ochiai similarity coefficients the isolates KFI-523 and KFI-392 showed a high degree of similarity and made a clear subgroup, while on 
Table 3 Genetic diversity indices for $F$. verticillioides, $F$. temperatum and $F$. subglutinans sensu stricto estimated on the basis of RAPD binary matrix

\begin{tabular}{|c|c|c|c|c|}
\hline \multirow[t]{2}{*}{ Diversity indices } & \multicolumn{3}{|l|}{ Species } & \multirow[t]{2}{*}{ Mean for species } \\
\hline & $F$. verticillioides & F. temperatum & F. subglutinansstrs.s. & \\
\hline The percentage of polymorphic loci (\%P) & $59.0 \%$ & $51.6 \%$ & $33.4 \%$ & $46.1 \%$ \\
\hline Nei’s genetic diversity $(\mathrm{h})$ & 0.180 & 0.127 & 0.098 & 0.303 \\
\hline Shannon-Weaver index (I) & 0.275 & 0.202 & 0.148 & 0.463 \\
\hline Coefficient of genetic differentiation $\left(\mathrm{G}_{\mathrm{ST}}\right)$ & 0.552 & & & \\
\hline Gene flow $\left(\mathrm{N}_{\mathrm{m}}\right)$ & 0.406 & & & \\
\hline
\end{tabular}

Kulczyński's dendrogram they were grouped in separate clusters (Fig. 3d).

The relationships of the analysed Fusarium species illustrated by the principal coordinate analysis (PCoA) (Fig. 4) were largely congruent with the UPGMA clustering. On the contrary to the UPGMA-based dendrograms however, groups designated as F.t. (containing 16 isolates) and as F.s. (nine isolates) were clearly separated from each other in the two-dimensional PCoA plots of 41 Fusarium strains.

The Neighbor-Net phylogenetic networks (Fig. 5) were generated for all Fusarium strains as well as for the separate species. The highest degree of genetic similarity was observed within $F$. subglutinans s.s. The results of the analysis show a remarkable diversity within $F$. verticillioides strains. Despite the same geographical origin, $F$. verticillioides strains are clustered into two distinct groups. While most of the $F$. verticillioides strains are grouped together, three MAT1-2 strains - KFI-522, KFI-

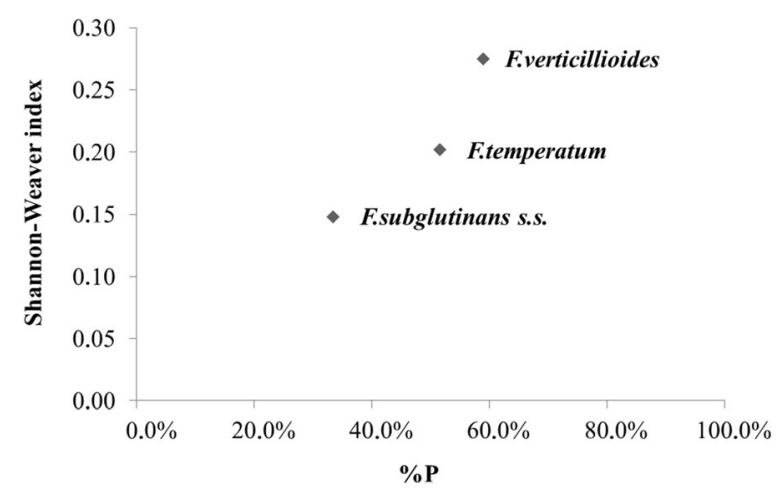

Fig. 2 The correlation between the level of genetic diversity and polymorphism of the $F$. verticillioides, $F$. temperatum and $F$. subglutinans sensu stricto populations expressed using the Shannon-Weaver index (y axis) and the percentage of polymorphic loci (x axis)
527, KFI-522 - form a distinct group. Combined with the mating type data the phylogenetic networks suggest the presence of a closer relationship between strains representing the same mating type (Fig. 5).

Although the phylogenetic analysis based on the translation elongation factor 1- $\alpha$ (EF 1- $\alpha$ ) and $\beta$-tubulin DNA sequences of $F$. temperatum and $F$. subglutinans sensu stricto does not support this conclusion, it indicates a high level of consistency with RAPD-based results in terms of the interspecies diversity (Fig. 6). Within species, however, the level of nucleotide similarity of the aforementioned regions was high and in the EF 1- $\alpha$ DNA sequences ranged from 98.1-100\% and 99.1-100\% for $F$. subglutinans s.s. and F. temperatum respectively, whereas the $\beta$-tubulin DNA sequences showed even higher similarity among tested strains (99.9-100\%).

The PHI test performed on the basis of the RAPD phylogenetic network (Fig. 5) detected 552 informative sites and found statistically significant evidence for recombination ( $p=9.653 \mathrm{E}-4)$ among the analysed Fusarium strains. This conclusion, however, was not supported by the DNA sequence data. Furthermore, the neutrality tests showed no evidence of selection in both EF 1- $\alpha$ and $\beta$-tubulin DNA sequences. Tajima's test values (D) for the sequences of analysed $F$. subglutinans sensu lato strains exceeded 1.5, but were not significant (Table 9).

Table 4 The level of gene flow $\left(\mathrm{N}_{\mathrm{m}}\right)$ between $F$. verticillioides, $F$. temperatum and F. subglutinans sensu stricto

$$
\text { F. verticillioides } \quad F \text {.temperatum }
$$

$\begin{array}{ll}\text { F. verticillioides } & \\ \text { F. temperatum } & 0.483 \\ \text { F. subglutinans s.s. } & 0.448\end{array}$

0.483
0.448

0.515 
Table 5 The genetic similarity of the analysed Fusarium spp. population estimated using four similarity coefficients

\begin{tabular}{lllll}
\hline Similarity coefficient & Min & Mean & Max & Coefficient of variation [\%] \\
\hline Dice & 0.186 & 0.440 & 0.945 & $50.13 \%$ \\
Jaccard & 0.103 & 0.312 & 0.896 & $68.94 \%$ \\
Kulczyński & 0.187 & 0.441 & 0.945 & $50.09 \%$ \\
Ochiai & 0.186 & 0.440 & 0.945 & $50.11 \%$ \\
\hline
\end{tabular}

\section{Discussion}

The present study on Fusarium species responsible for the pink ear rot of maize reveals a moderate level of genetic variation with $46.1 \%$ of loci being polymorphic and even higher polymorphism at the species level.

The largest number of polymorphic loci (59\%) as well as the highest diversity was recorded within the population of $F$. verticillioides isolates. The Nei's genetic diversity was estimated at 0.180 while the Shannon-Weaver index reached 0.275. Similar results for this species were reported by Reynoso et al. (2009) with the gene diversity value of 0.128 and the percentage of polymorphic loci ranging from 48 to $52 \%$.

The analysed $F$. verticillioides population reveals one of the lowest so far values of genetic similarity of 0.610 . Other studies showed much higher genetic similarity of $F$. verticillioides populations: 0.73 (Leslie et al. 2005), 0.76 (Leslie et al. 2004) and 0.91 (Reynoso et al. 2009).

As indicated by the values of Nei's genetic diversity (0.127), the Shannon-Weaver index (0.202) and the percentage of polymorphic bands $(51.6 \%)$, the analysed population of $F$. temperatum strains exhibited slightly lower level of diversity than $F$. verticillioides. Genetic similarity coefficients (GS) between the $F$. temperatum strains ranged from 0.453 to 0.933 , with a mean of 0.731. Similar results were obtained by examination of

Table 6 Correlation coefficients between measures of genetic similarity

\begin{tabular}{llll}
\hline Similarity coefficient & Dice & Jaccard & Kulczyński \\
\hline Jaccard & 0.99667 & & \\
Kulczyński & 0.99998 & 0.99661 & \\
Ochiai & 0.99999 & 0.99664 & 0.99999 \\
\hline
\end{tabular}

F. temperatum isolated from maize in Belgium (Scauflaire et al. 2011), where the genetic similarity ranged from 0.74 to 1.00 .

The result of the present study using RAPD reveals very low level of genetic diversity within the population of $F$. subglutinans sensu stricto with an average Nei's genetic diversity estimated at 0.098 , the ShannonWeaver index -0.148 and only $33.4 \%$ polymorphic amplification products observed. Regardless of the diverse origin of isolates, F.subglutinans s.s. shows a fairly high level of genetic similarity ranging from 0.616 to 0.876 with mean value of 0.762 .

As evidenced by the values of gene diversity $(0.303)$ and the Shannon-Weaver index (0.463), the genetic diversity within the analysed Fusarium spp. strains is

Table 7 The genetic similarity of $F$. verticillioides, $F$. temperatum and $F$. subglutinans sensu stricto estimated using four similarity coefficients: Dice, Jaccard, Kulczyński and Ochiai

\begin{tabular}{llllll}
\hline Species & $\begin{array}{l}\text { Similarity } \\
\text { coefficient }\end{array}$ & Min & Mean & Max & $\begin{array}{l}\text { Variability } \\
{[\%]}\end{array}$ \\
\hline F. verticillioides & Dice & 0.336 & 0.645 & 0.885 & $28.96 \%$ \\
& Jaccard & 0.202 & 0.502 & 0.794 & $38.16 \%$ \\
& Kulczyński & 0.336 & 0.646 & 0.885 & $28.95 \%$ \\
& Ochiai & 0.336 & 0.646 & 0.885 & $28.95 \%$ \\
& Mean & 0.302 & 0.610 & 0.862 & $31.25 \%$ \\
F. temperatum & Dice & 0.494 & 0.764 & 0.945 & $14.46 \%$ \\
& Jaccard & 0.328 & 0.630 & 0.896 & $21.07 \%$ \\
& Kulczyński & 0.495 & 0.765 & 0.945 & $14.46 \%$ \\
& Ochiai & 0.494 & 0.764 & 0.945 & $14.46 \%$ \\
F. subglutinans & Mean & 0.453 & 0.731 & 0.933 & $16.11 \%$ \\
& Dice & 0.656 & 0.794 & 0.897 & $6.77 \%$ \\
& Jaccard & 0.488 & 0.662 & 0.813 & $11.09 \%$ \\
& Kulczyński & 0.663 & 0.797 & 0.897 & $6.61 \%$ \\
& Ochiai & 0.659 & 0.795 & 0.897 & $6.69 \%$ \\
& Mean & 0.616 & 0.762 & 0.876 & $7.79 \%$ \\
\hline
\end{tabular}


a

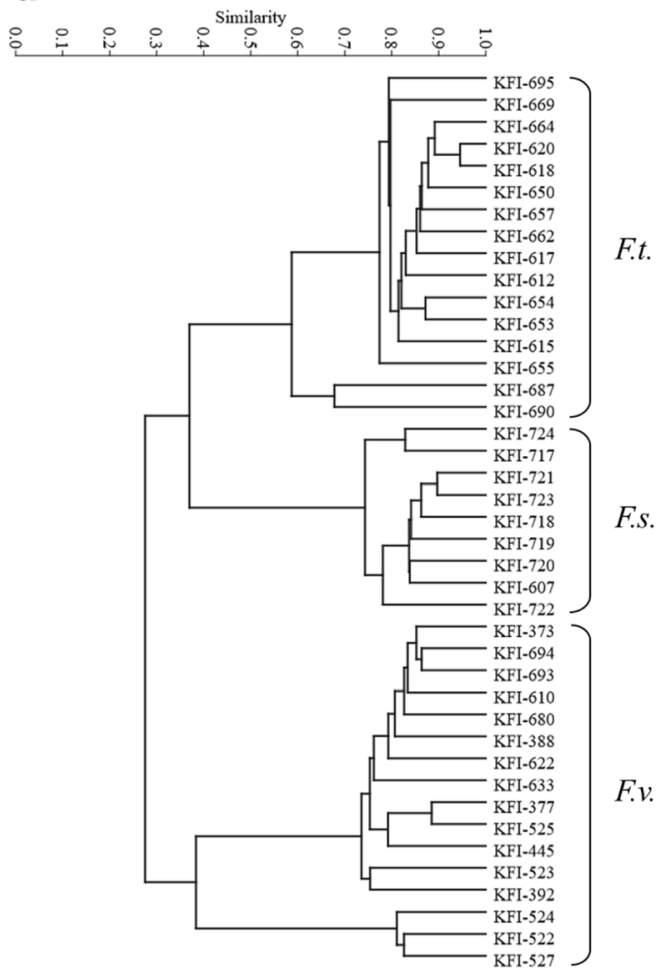

C

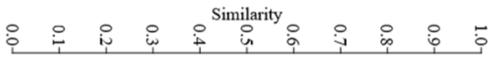

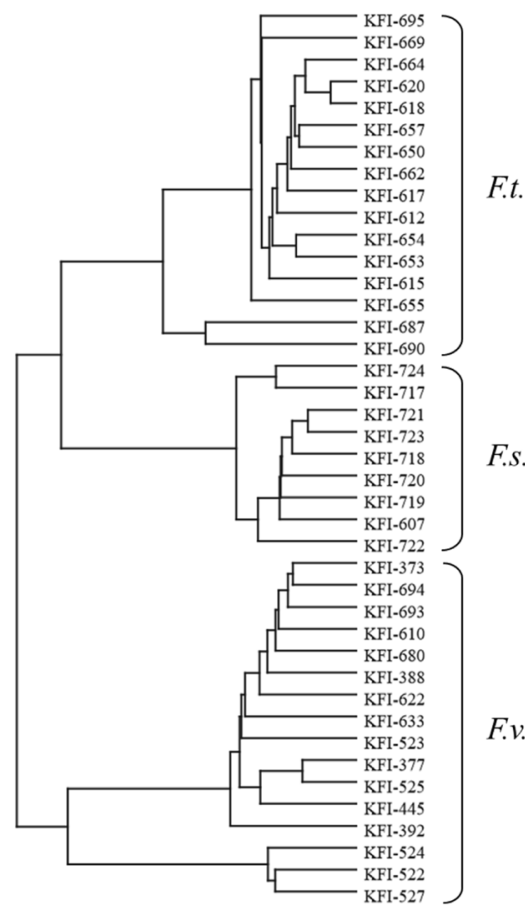

Fig. 3 UPGMA dendrogram illustrating the genetic relationships among analysed Fusarium spp. strains, generated from RAPD data on the basis of four similarity coefficients: Dice (a), Jaccard b

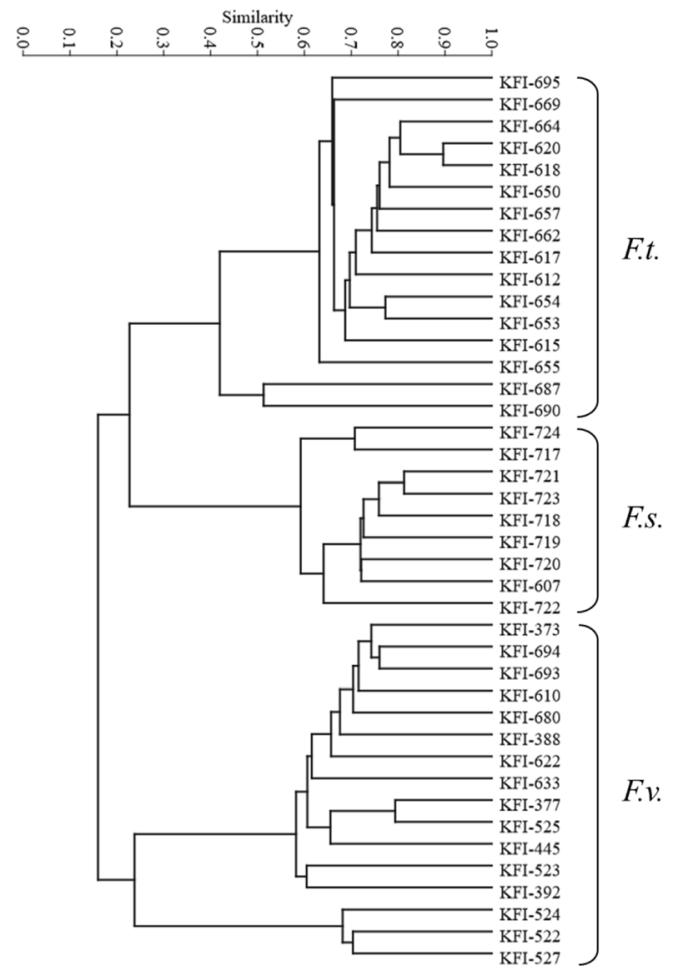

d

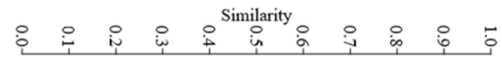

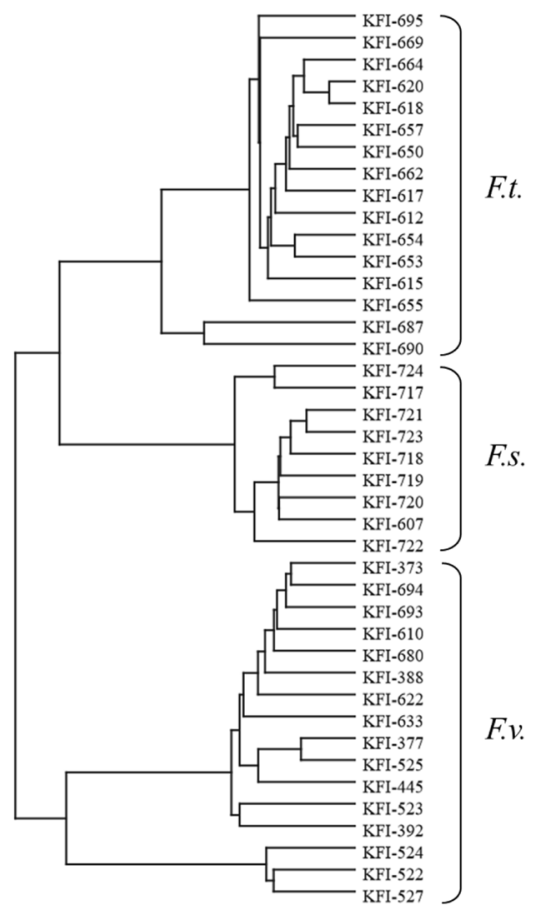

(b), Kulczyński (c) and Ochiai (d). The groups of F.temperatum isolates are labelled F.t., F. subglutinans s.s. - F.s. and F. verticillioides - F.v 
Table 8 The genetic similarity (values above diagonal) and diversity (below diagonal) between three Fusarium species: F. verticillioides, F. temperatum and F. subglutinans sensu stricto

\begin{tabular}{llll}
\hline & F. verticillioides & F. temperatum & F. subglutinans s.s. \\
\hline F. verticillioides & & 0.706 & 0.698 \\
F. temperatum & 0.348 & & 0.732 \\
F. subglutinans s.s. & 0.359 & 0.313 & \\
\hline
\end{tabular}

at a fairly high level. The genetic diversity within the species of Fusarium fujikuroi species complex seems to be one of the supporting arguments for the regular occurrence of sexual reproduction process. The results of the current study prove that gene recombination occurring during sexual reproduction may be the source of the observed genetic diversity in these anamorphic fungi. What is more, the presence of numerous unique genotypes identified by the molecular markers such as RAPD indicates a small percentage of clones in the population. It is worth noting that all of the $F$. verticillioides and $F$. temperatum isolates originated from one location.

The $\mathrm{G}_{\mathrm{ST}}$ value of 0.552 indicates that $61 \%$ of variation is found within analysed populations of $F$. verticillioides, $F$. temperatum and $F$. subglutinans sensu stricto and only $39 \%$ is observed within a species. Such result is in agreement with the very low level of the gene flow between species $\left(\mathrm{N}_{\mathrm{m}}=0.406\right)$. It is commonly considered that a $\mathrm{G}_{\mathrm{ST}}$ value higher than " 0.25 " indicates a very high level of population differentiation (Berg and Hamrick 1997), while the $\mathrm{N}_{\mathrm{m}}$ value below " 1 " allows to conclude that there is no gene exchange between species (McDonald 1997).

While the principal coordinate analysis (PCoA) based on 17 RAPD marker profiles has grouped the Fusarium strains into the three clusters according to their taxonomic classification, the UPGMA cluster analysis has grouped all the 41 Fusarium strains into two clusters only. The pattern of clustering visible on the dendrograms clearly reflects the level of genetic differentiation between the analysed species: $F$. verticillioides, $F$. temperatum and $F$. subglutinans s.s. The F.temperatum and F.subglutinans s.s. strains are clustered into one because of their close phylogenetic relationship and high level of morphological similarity. The clustering of strains remains more or less the same on all the dendrograms regardless of the similarity coefficient used for the analysis.

Surprisingly, despite the fact that the similarity coefficients selected for the analysis are based on different interpretations of the shared absences of specific bands in the amplification profile - while Ochiai's coefficient includes negative co-occurrences, Jaccard's, Dice's and Kulczynski's coefficients include only positive matches - the patterns of diversity revealed by all of the similarity measures are statistically the same. The results of this study indicate that the Jaccard's coefficient - most commonly used next to the Dice index - may strengthen the observed diversity. This index is also considered to be the most appropriate measure of similarity for haploid organisms with dominant markers such as RAPD, AFLP and ISSR, especially for individuals from different taxa (Kosman and Leonard 2005), while Dice's measure is recommended for the comparison analysis of individuals with low levels of similarity as it places more weight on the shared bands (Weising et al. 2005).

To provide a broader level of resolution, the translation elongation factor $1-\alpha$ and $\beta$-tubulin gene sequence analysis was employed to support the RAPD data obtained in this study. The phylogenetic analysis of the aforementioned regions was in agreement with the RAPD results and supported the separation of species into distinct clades. In terms of the interspecies diversity, both analyses showed similar results indicating higher variation occurring between species than among species. Although phylogenetic network analysis of the RAPD data together with the PHI test suggests the presence of recombination events in the analysed population, no substantial evidence of recombination was detected within the analysed nucleotide sequences.

Although the RAPD based analysis is considered to be a low reproducibility technique (He et al. 1994; 
a

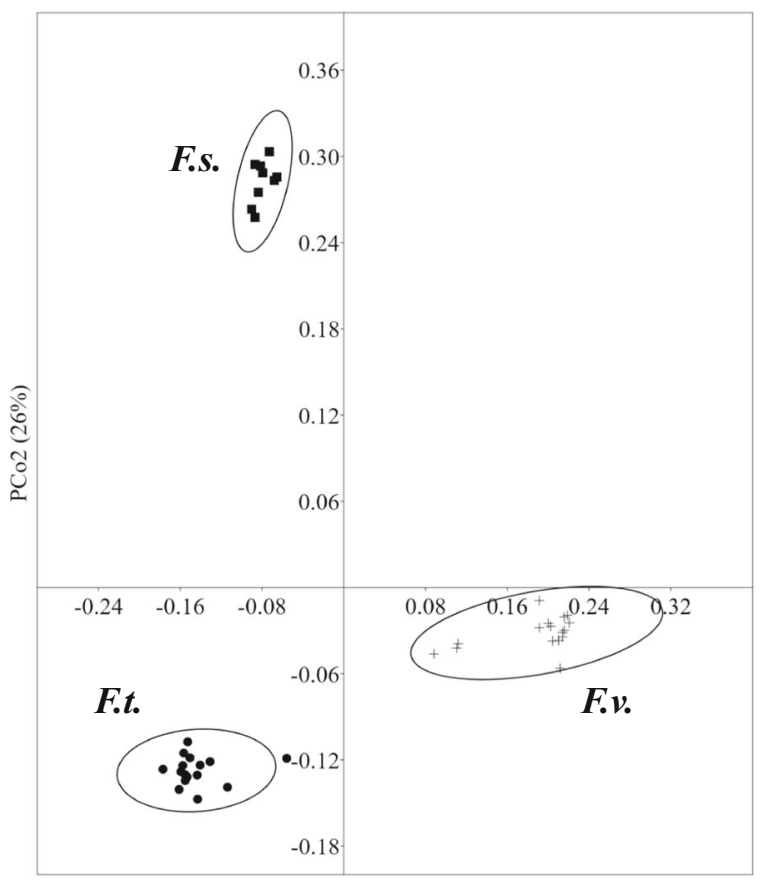

PCol $(46.2 \%)$

C

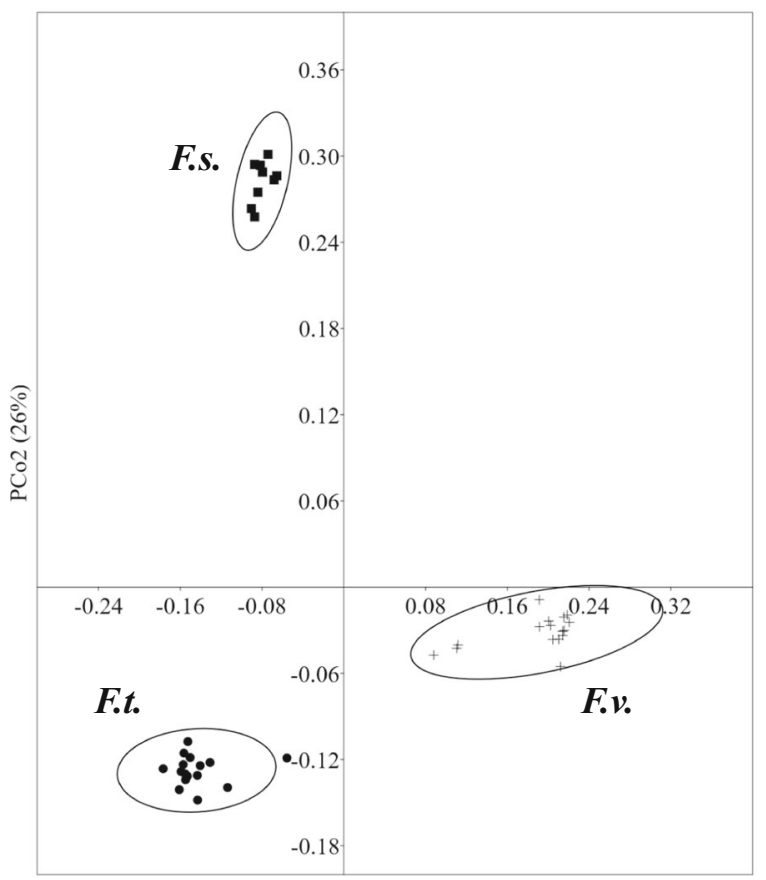

PCol $(46.3 \%)$

Fig. 4 The phylogenetic relationships of the analysed Fusarium species: F. verticillioides (F.v.), F. temperatum (F.t.) and $F$. subglutinans sensu stricto (F.s.) illustrated by two- b
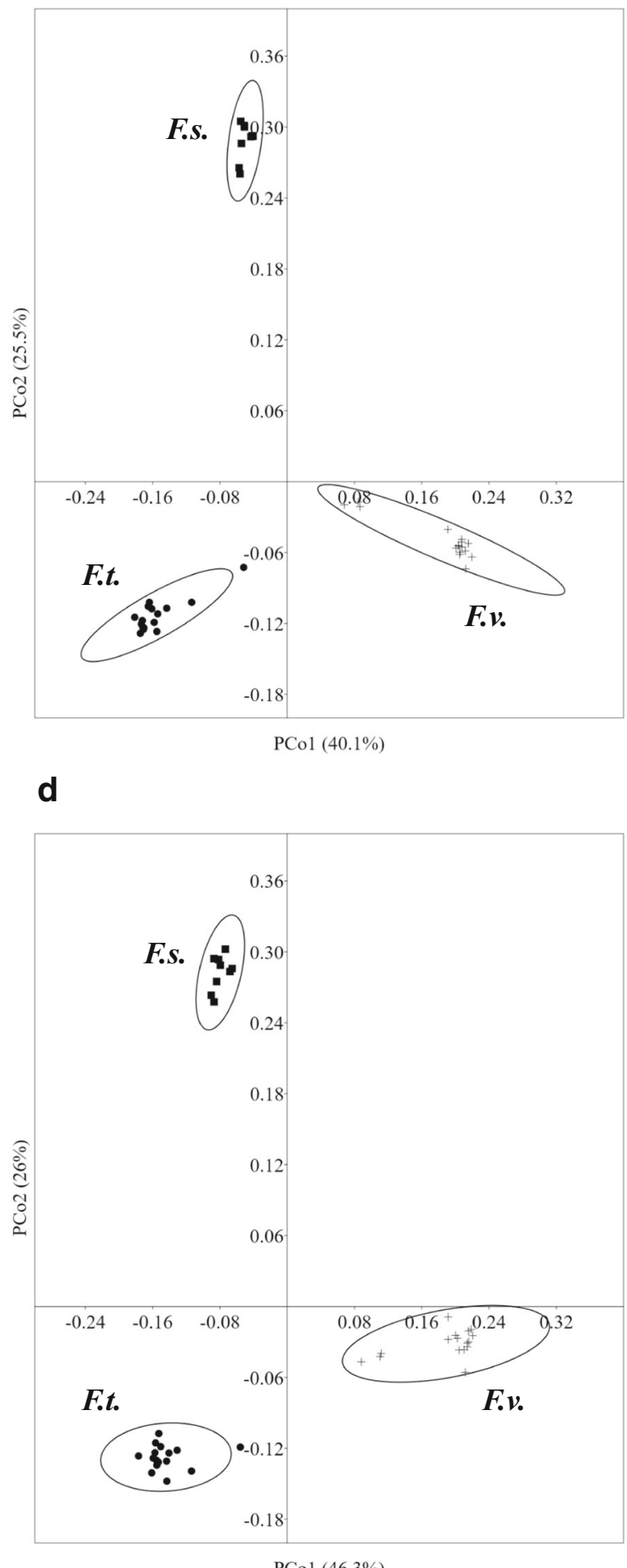

PCol (46.3\%)

dimensional plots obtained using principal coordinates analysis (PCoA) generated from RAPD data on the basis of four similarity coefficients: Dice (a), Jaccard (b), Kulczyński (c) and Ochiai (d) 


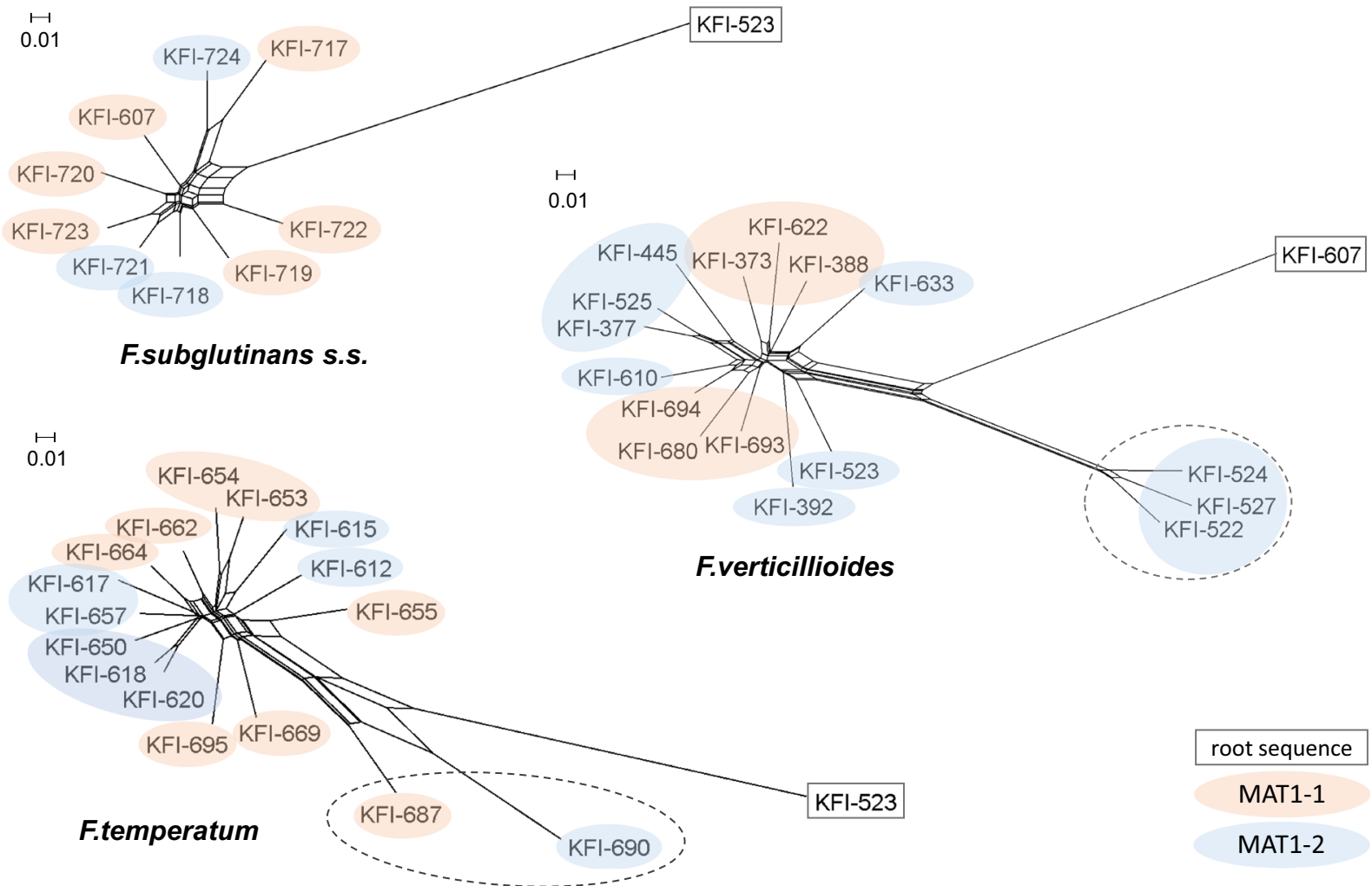

Fig. 5 Neighbor-Net phylogenetic network explaining the genetic diversity within the analysed Fusarium species: F. verticillioides, $F$. temperatum and $F$. subglutinans sensu stricto on the basis of the
RAPD data. For each species analysis, the most distant strain representing other taxon was used as an outgroup

(Reynoso et al. 2009; Brake et al. 2014; Zargar et al. 2016). Therefore, RAPD has been widely used in the assessment of genetic similarity (Singh et al. 2006), in the analysis of genetic diversity within a species (Collignon et al. 2002) or between closely related species (Jiménez et al. 2000). Within Fusarium genus, RAPD has been applicable e.g. in the distinction between nonpathogenic and pathogenic isolates of $F$. oxysporum $\mathrm{f}$. $\mathrm{sp}$. dianthi (Manulis et al. 1994), differentiation of special forms of $F$. oxysporum pathogenic to cucumber (Vakalounakis and Fragkiadakis 1999) or in $F$. verticillioides strains differentiation depending on the host plant (Kini et al. 2002).

In this study, the use of RAPD markers proved to be useful and efficient tool to detect the amount of polymorphism in Fusarium species associated with the pink ear rot of maize. As expressed by the percentage of polymorphic bands per single assay unit, the effectiveness of the RAPD analysis reached 8.56. Similar result of 10 polymorphic band per assay were obtained by Pamphile 


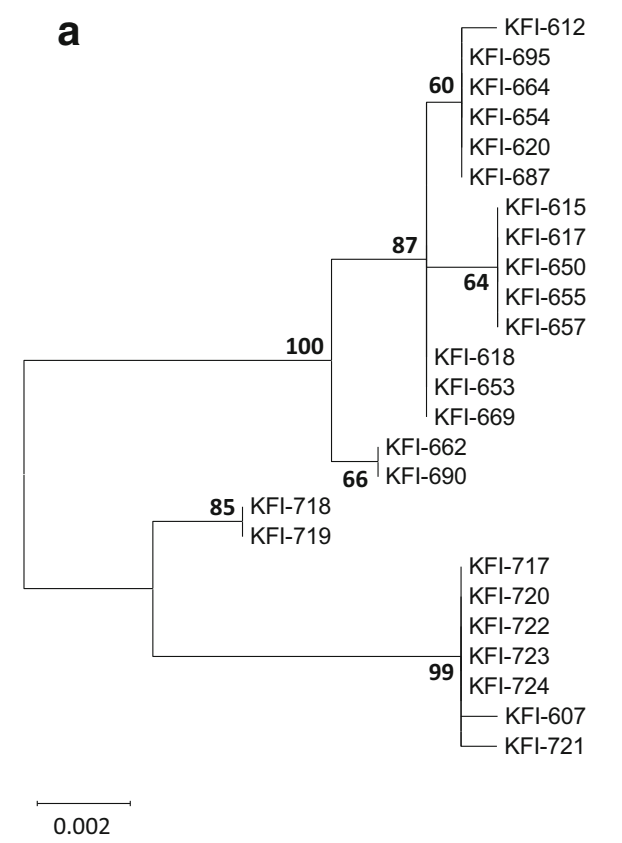

Fig. 6 Maximum likelihood trees based on the concatenated $\beta$ tubulin and translation elongation factor $1-\alpha$ gene DNA sequences of the analysed $F$. temperatum and $F$. subglutinans sensu stricto strains. Both trees were constructed using Kimura's two-parameter model - as determined by the model test algorithm implemented in MEGA 7.0.6 - and tested by bootstrapping (1000 replicates). a

and Azevedo (2002) in the analysis of $F$. verticillioides population obtained from corn in Brazil.

The discriminatory power of RAPD markers used in this study was determined using various parameters. The highest efficiency was demonstrated by the primers

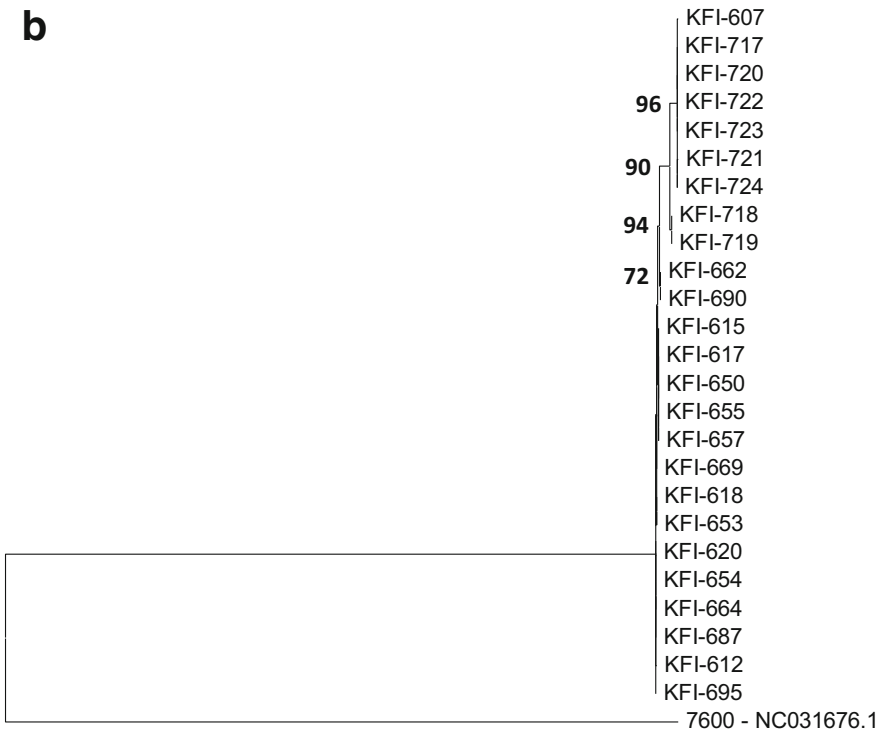

0.3

Phylogenetic tree showing the relationships between studied $F$. temperatum and $F$. subglutinans sensu stricto strains. b Genetic divergence between $F$. subglutinans sensu stricto and F. verticillioides. F. verticillioides strain 7600 (Sequence ID: NC_031676.1) was used as an outgroup. The scale bar represents the number of substitutions per site

OPAA 09 and OPAD 12, which were characterized by the highest parameters' values: the marker index of 2.75 for both primers, the effective multiplex ratio $(10.70$; 9.92) and the percentage of polymorphic loci of $62.1 \%$ and $68.3 \%$, respectively.

Table 9 Sequence diversity of the translation elongation factor $1-\alpha$ and $\beta$-tubulin gene among $F$. temperatum and $F$. subglutinans sensu stricto strains

\begin{tabular}{|c|c|c|c|c|c|c|c|c|c|}
\hline Locus & Species & $\mathrm{bp}$ & $\mathrm{n}$ & $\mathrm{GC} \%$ & $\mathrm{~h}$ & $\mathrm{~s}$ & $\pi$ & $\Theta$ & $D$ \\
\hline \multirow[t]{3}{*}{$\beta$-tubulin } & & 721 & 25 & 55.3 & 4 & 6 & 0.00291 & 0.00222 & 0.92422 \\
\hline & F.subglutinans & & 9 & 55.8 & 2 & 1 & 0.00031 & 0.00051 & -1.08823 \\
\hline & F.temperatum & & 16 & 55.2 & 2 & 1 & 0.00017 & 0.00041 & -1.16221 \\
\hline \multirow[t]{3}{*}{ EF $1-\alpha$} & & 582 & 25 & 51.6 & 7 & 20 & 0.01474 & 0.01017 & 1.62650 \\
\hline & F.subglutinans & & 9 & 51.4 & 3 & 10 & 0.00713 & 0.00705 & 0.05422 \\
\hline & F.temperatum & & 16 & 51.8 & 4 & 6 & 0.00383 & 0.00317 & 0.71015 \\
\hline \multirow[t]{3}{*}{ Concatenated sequences } & & 1331 & 25 & 53.7 & 9 & 26 & 0.00790 & 0.00557 & 1.54449 \\
\hline & F.subglutinans & & 9 & 54.0 & 4 & 11 & 0.00317 & 0.00326 & -0.11945 \\
\hline & F.temperatum & & 16 & 53.7 & 5 & 7 & 0.00176 & 0.00161 & 0.33201 \\
\hline
\end{tabular}

$b p$ - sequence length in base pairs; $n$ - number of sequences; GC\% - GC content; $s$ - number of segregating sites; $h$ - number of haplotypes; $\pi$ nucleotide diversity; $\Theta$ - estimate of Theta per site; D - Tajima's test statistic 
Acknowledgements This study was partially supported by the project no. 92 of the Ministry of Agriculture and Rural Development.

\section{Compliance with ethical standards}

Conflict of interest The authors declare that they have no conflict of interest.

Human participants and/or animals This work does not contain any studies with human participants or animals performed by any of the authors.

Open Access This article is licensed under a Creative Commons Attribution 4.0 International License, which permits use, sharing, adaptation, distribution and reproduction in any medium or format, as long as you give appropriate credit to the original author(s) and the source, provide a link to the Creative Commons licence, and indicate if changes were made. The images or other third party material in this article are included in the article's Creative Commons licence, unless indicated otherwise in a credit line to the material. If material is not included in the article's Creative Commons licence and your intended use is not permitted by statutory regulation or exceeds the permitted use, you will need to obtain permission directly from the copyright holder. To view a copy of this licence, visit http://creativecommons.org/licenses/by/4.0/.

\section{References}

Berg, E. E., \& Hamrick, J. L. (1997). Quantification of genetic diversity at allozyme loci. Canadian Journal of Forest Research, 27(3), 415-424. https://doi.org/10.1139/cjfr-27-3-415.

Botstein, D., White, R. L., Skolnick, M., \& Davis, R. W. (1980). Construction of a genetic linkage map in man using restriction fragment length polymorphisms. American Journal of Human Genetics, 32(3), 314-331.

Brake, M., Migdadi, H., Al-Gharaibeh, M., Ayoub, S., Haddad, N., \& El Oqlah, A. (2014). Characterization of Jordanian olive cultivars (Olea europaea L.) using RAPD and ISSR molecular markers. Scientia Horticulturae, 176, 282-289. https://doi.org/10.1016/j.scienta.2014.07.012.

Britz, H., Coutinho, T. A., Wingfield, M. J., Marasas, W. F. O., Gordon, T. R., \& Leslie, J. F. (1999). Fusarium subglutinans f. sp. Pini represents a distinct mating population in the Gibberella fujikuroi species complex. Applied and Environmental Microbiology, 65(3), 1198-1201.

Britz, H., Steenkamp, E. T., Coutinho, T. A., Wingfield, B. D., Marasas, W. F., \& Wingfield, M. J. (2002). Two new species of Fusarium section Liseola associated with mango malformation. Mycologia, 94(4), 722-730. https://doi.org/10.1080 /15572536.2003.11833199.

Bruen, T. C., Philippe, H., \& Bryant, D. (2006). A simple and robust statistical test for detecting the presence of recombination. Genetics, 172(4), 2665-2681. https://doi.org/10.1534 /genetics.105.048975.
Burgess, L. W., \& Liddell, C. M. (1983). Laboratory manual for Fusarium research. Sydney, Australia: The University of Sydney.

Collignon, A. M., Sype, H. V. D., \& Favre, J. M. (2002). Geographical variation in random amplified polymorphic DNA and quantitative traits in Norway spruce. Canadian Journal of Forest Research, 32(2), 266-282. https://doi. org/10.1139/x01-198.

De Riek, J., Calsyn, E., Everaert, I., Van Bockstaele, E., \& De Loose, M. (2001). AFLP based alternatives for the assessment of distinctness, uniformity and stability of sugar beet varieties. Theoretical and Applied Genetics, 103(8), 1254 1265. https://doi.org/10.1007/s001220100710.

Desjardins, A. E. (2006). Fusarium mycotoxins: chemistry,genetics and biology. Saint Paul: APS, 268 pp.

Dice, L. R. (1945). Measures of the amount of ecologic association between species. Ecology, 26(3), 297-302. https://doi. org/10.2307/1932409.

Doohan, F. M., Parry, D. W., Jenkinson, P., \& Nicholson, P. (1998). The use of species-specific PCR-based assays to analyse Fusarium ear blight of wheat. Plant Pathology, 47(2), 197205. https://doi.org/10.1046/j.1365-3059.1998.00218.x.

El-Yazeed, H. A., Hassan, A., Moghaieb, R. E., Hamed, M., \& Refai, M. (2011). Molecular detection of fumonisinproducing Fusarium species in animal feeds using polymerase chain reaction (PCR). Journal of Applied Sciences Research, 7(4), 420-427.

Geiser, D. M., del Mar Jiménez-Gasco, M., Kang, S., Makalowska, I., Veeraraghavan, N., Ward, T. J., Zhang, N., Kuldau, G. A., \& O'donnell, K. (2004). FUSARIUM-ID v. 1.0: A DNA sequence database for identifying Fusarium. European Journal of Plant Pathology, 110(5-6), 473-479. https://doi.org/10.1023/B:EJPP.0000032386.75915.a0.

Hammer, Ø., Harper, D. A. T., \& Ryan, P. D. (2001). PASTpalaeontological statistics, ver. 1.89. Palaeontologia Electronica, 4(1), 1-9.

Harrow, S. A., Farrokhi-Nejad, R., Pitman, A. R., Scott, I. A., Bentley, A., Hide, C., et al. (2010). Characterisation of New Zealand Fusarium populations using a polyphasic approach differentiates the $F$. avenaceum / $F$. acuminatum / $F$. tricinctum species complex in cereal and grassland systems. Fungal Biology, 114(4), 293-311. https://doi. org/10.1016/j.funbio.2010.01.005.

He, Q., Viljanen, M. K., \& Mertsola, J. (1994). Effects of thermocyclers and primers on the reproducibility of banding patterns in randomly amplified polymorphic DNA analysis. Molecular and Cellular Probes, 8(2), 155-159. https://doi. org/10.1006/mcpr.1994.1021.

Hsuan, H. M., Salleh, B., \& Zakaria, L. (2011). Molecular identification of Fusarium species in Gibberella fujikuroi species complex from rice, sugarcane and maize from peninsular Malaysia. International Journal of Molecular Sciences, 12(10), 6722-6732. https://doi.org/10.3390/ijms12106722.

Huson, D. H., \& Bryant, D. (2006). Application of phylogenetic networks in evolutionary studies. Molecular Biology and Evolution, 23(2), 254-267. https://doi.org/10.1093 /molbev/msj030.

IARC. (1993). IARC monographs on the evaluation of carcinogenic risks to humans Vol, 56. Some naturally occurring substances: Food items and constituents, heterocyclic aromatic amines and mycotoxins (599 pp). Lyon, France: International Agency for Research on Cancer. 
Iqbal, Z., Dasti, A. A., Saleem, A., \& Zafar, Y. (2006). RAPD analysis of Fusarium isolates causing "mango malformation" disease in Pakistan. World Journal of Microbiology and Biotechnology, 22(11), 1161-1167. https://doi.org/10.1007 /s11274-006-9157-x.

Jaccard, P. (1908). Nouvelles recherches sur la distribution florale. Bulletin de la Société vaudoise des sciences naturelles, 44, 223-270 (in French).

Jiménez, M., Rodríguez, S., Mateo, J. J., Gil, J. V., \& Mateo, R. (2000). Characterization of Gibberella fujikuroi complex isolates by fumonisin B1 and B2 analysis and by RAPD and restriction analysis of PCR-amplified internal transcribed spacers of ribosomal DNA. Systematic and Applied Microbiology, 23(4), 546-555. https://doi.org/10.1016 /S0723-2020(00)80029-6.

King, D., Rhine-Chalberg, J., Pfaller, M. A., Moser, S. A., \& Merz, W. G. (1995). Comparison of four DNA-based methods for strain delineation of Candida lusitaniae. Journal of Clinical Microbiology, 33(6), 467-1470.

Kini, K. R., Leth, V., \& Mathur, S. B. (2002). Genetic variation in Fusarium moniliforme isolated from seeds of different host species from Burkina Faso based on random amplified polymorphic DNA analysis. Journal of Phytopathology, 150(4-5), 209212. https://doi.org/10.1046/j.1439-0434.2002.00739.x.

Knutsen, A. K., Torp, M., \& Holst-Jensen, A. (2004). Phylogenetic analyses of the Fusarium poae, Fusarium sporotrichioides and Fusarium langsethiae species complex based on partial sequences of the translation elongation factor-1 alpha gene. International Journal of Food Microbiology, 95(3), 287-295. https://doi.org/10.1016/j.ijfoodmicro.2003.12.007.

Kosman, E., \& Leonard, K. J. (2005). Similarity coefficients for molecular markers in studies of genetic relationships between individuals for haploid, diploid, and polyploid species. Molecular Ecology, 14(2), 415-424. https://doi.org/10.1111 j.1365-294X.2005.02416.x.

Kulczyński, S. (1927). Die Pflanzenassoziationen der Pieninen. Bulletin International de l'Académie Polonaise des Sciences et des Letters, Classe des Sciences Mathematiques et Naturelles, Serie B, Supplément II, 2, 57-203 (in Polish with an abstract in German).

Kumar, S., Stecher, G., \& Tamura, K. (2016). MEGA7: Molecular evolutionary genetics analysis version 7.0 for bigger datasets. Molecular Biology and Evolution, 33(7), 1870-1874. https://doi.org/10.1093/molbev/msw054.

Kvas, M., Marasas, W. F. O., Wingfield, B. D., Wingfield, M. J., \& Steenkamp, E. T. (2009). Diversity and evolution of Fusarium species in the Gibberella fujikuroi complex. Fungal Diversity, 34, 1-21.

Lamprecht, S. C., Marasas, W. F. O., Alberts, J. F., Cawood, M. E., Gelderblom, W. C. A., Shephard, G. S., Thiel, P. G., \& Calitz, F. J. (1994). Phytotoxicity of fumonisins and TAtoxin to corn and tomato. Phytopathology, 84(4), 383-391. https://doi.org/10.1094/Phyto-84-383.

Latiffah, Z., MZ, N. H., Baharuddin, S., \& Maziah, Z. (2008). Vegetative compatibility group of Fusarium species associated with root and stem rot of orchid. Malaysian Journal of Microbiology, 4(1), 49-52. https://doi.org/10.21161/mjm.02208.

Leslie, J. F. (1995). Gibberella fujikuroi: available populations and variable traits. Canadian Journal of Botany, 73(S1), 282291. https://doi.org/10.1139/b95-258.
Leslie, J. F., Summerell, B. A. (2006). The Fusarium Laboratory Manual. Oxford, USA: Blackwell Publishing, https://oi. org/10.1002/9780470278376, pp. 388.

Leslie, J. F., Zeller, K. A., Wohler, M., \& Summerell, B. A. (2004). Interfertility of two mating populations in the Gibberella fujikuroi species complex. European Journal of Plant Pathology, 110(5-6), 611-618. https://doi.org/10.1007 /978-1-4020-2285-2_15.

Leslie, J. F., Zeller, K. A., Lamprecht, S. C., Rheeder, J. P., \& Marasas, W. F. (2005). Toxicity, pathogenicity, and genetic differentiation of five species of Fusarium from sorghum and millet. Phytopathology, 95(3), 275-283. https://doi. org/10.1094/PHYTO-95-0275.

Lin, D., Lehmann, P. F., Hamory, B. H., Padhye, A. A., Durry, E., Pinner, R. W., \& Lasker, B. A. (1995). Comparison of three typing methods for clinical and environmental isolates of Aspergillus fumigatus. Journal of Clinical Microbiology, 33(6), 1596-1601.

Logrieco, A., \& Visconti, A. (Eds.). (2004). An overview on toxigenic fungi and mycotoxins in Europe (268 pp). Kluwer Academic: Springer Science \& Business Media. https://doi. org/10.1007/978-1-4020-2646-1.

MacPherson, J. M., Eckstein, P. E., Scoles, G. J., \& Gajadhar, A. A. (1993). Variability of the random amplified polymorphic DNA assay among thermal cyclers, and effects of primer and DNA concentration. Molecular and Cellular Probes, 7(4), 293-299. https://doi.org/10.1006/mcpr.1993.1043.

Manulis, S., Kogan, N., Reuven, M., \& Ben-Yephet, Y. (1994). Use of the RAPD technique for identification of Fusarium oxysporum f. sp. Dianthi from carnation. Phytopathology, 84(1), 98-101. https://doi.org/10.1094/Phyto-84-98.

McDermott, J. M., \& McDonald, B. A. (1993). Gene flow in plant pathosystems. Annual Review of Phytopathology, 31(1), 353-373. https://doi.org/10.1146/annurev.phyto.31.1.353.

McDonald, B. A. (1997). The population genetics of fungi: Tools and techniques. Phytopathology, 87(4), 448-453. https://doi. org/10.1094/PHYTO.1997.87.4.448.

Meunier, J. R., \& Grimont, P. A. (1993). Factors affecting reproducibility of random amplified polymorphic DNA fingerprinting. Research in Microbiology, 144(5), 373-379. https://doi.org/10.1016/0923-2508(93)90194-7.

Mohammadian, E., Javan-Nikkhah, M., Okhovvat, S. M., \& Ghazanfari, K. (2011). Study on genetic diversity of Gibberella moniliformis and G. intermedia from corn and rice, and determination of fertility status and of mating type alleles. Australian Journal of Crop Science, 5(11), 1448-1454.

Mulè, G., Susca, A., Stea, G., \& Moretti, A. (2004). A speciesspecific PCR assay based on the calmodulin partial gene for identification of Fusarium verticillioides. F. proliferatum and F. subglutinans. European Journal of Plant Pathology, 110(5-6), 495-502. https://doi.org/10.1023 /B:EJPP.0000032389.84048.71.

Mułenko, W., Majewski, T., \& Ruszkiewicz-Michalska, M. (2008). A preliminary checklist of Micromycetes in Poland. Kraków, Poland: W. Szafer Institute of Botany, Polish Academy of Sciences.

Nei, M. (1973). Analysis of gene diversity in subdivided populations. Proceedings of the National Academy of Sciences, 70(12), 3321-3323. https://doi.org/10.1073/pnas.70.12.3321.

Nei, M., \& Li, W. H. (1979). Mathematical model for studying genetic variation in terms of restriction endonucleases. 
Proceedings of the National Academy of Sciences, 76(10), 5269-5273. https://doi.org/10.1073/pnas.76.10.5269.

Nelson, P. E., Toussoun, A., \& Marasas, W. F. O. (1983). Fusarium species: An illustrated manual for identification (p. 206). The Pennsylvania State University Press: University Park, Pennsylvania, USA.

Nirenberg, H. I., \& O'Donnell, K. (1998). New Fusarium species and combinations within the Gibberella fujikuroi species complex. Mycologia, 90(3), 434-458. https://doi. org/10.1080/00275514.1998.12026929.

Ochiai, A. (1957). Zoogeographic studies on the soleoid fishes found in Japan and its neighbouring regions. Bulletin of Japanese Society of Scientific Fisheries, 22, 526-530. https://doi.org/10.2331/suisan.22.526.

O'Donnell, K., \& Cigelnik, E. (1997). Two divergent intragenomic rDNA ITS2 types within a monophyletic lineage of the fungus Fusarium are nonorthologous. Molecular Phylogenetics and Evolution, 7(1), 103-116. https://doi. org/10.1006/mpev.1996.0376.

O'Donnell, K., Cigelnik, E., \& Casper, H. H. (1998a). Molecular phylogenetic, morphological, and mycotoxin data support reidentification of the Quorn mycoprotein fungus as Fusarium venenatum. Fungal Genetics and Biology, 23(1), 57-67. https://doi.org/10.1006/fgbi.1997.1018.

O'Donnell, K., Kistler, H. C., Cigelnik, E., \& Ploetz, R. C. (1998b). Multiple evolutionary origins of the fungus causing Panama disease of banana: Concordant evidence from nuclear and mitochondrial gene genealogies. Proceedings of the National Academy of Sciences, 95(5), 2044-2049. https://doi.org/10.1073/pnas.95.5.2044.

Otero-Colina, G., Rodríguez-Alvarado, G., Fernández-Pavía, S., Maymon, M., Ploetz, R. C., Aoki, T., O'Donnell, K., \& Freeman, S. (2010). Identification and characterization of a novel etiological agent of mango malformation disease in Mexico. Fusarium mexicanum sp. nov. Phytopathology, 100(11), 1176-1184. https://doi.org/10.1094/PHYTO-01-10-0029.

Pamphile, J. A., \& Azevedo, J. L. (2002). Molecular characterization of endophytic strains of Fusarium verticillioides (= Fusarium moniliforme) from maize (Zea mays L.). World Journal of Microbiology and Biotechnology, 18(5), 391-396. https://oi.org/10.1023/A:1015507008786.

Peakall, R. O. D., \& Smouse, P. E. (2006). GenAlEx 6: Genetic analysis in excel. Population genetic software for teaching and research. Molecular Ecology Notes, 6(1), 288-295. https://doi.org/10.1111/j.1471-8286.2005.01155.x.

Peakall, R. O. D., \& Smouse, P. E. (2012). GenAlEx 6.5: Genetic analysis in excel. Population genetic software for teaching and research - An update. Bioinformatics, 28(19), 25372539. https://doi.org/10.1093/bioinformatics/bts460.

Powell, W., Morgante, M., Andre, C., Hanafey, M., Vogel, J., Tingey, S., \& Rafalski, A. (1996). The comparison of RFLP, RAPD, AFLP and SSR (microsatellite) markers for germplasm analysis. Molecular Breeding, 2(3), 225-238. https://doi.org/10.1007/BF00564200.

Prevost, A., \& Wilkinson, M. J. (1999). A new system of comparing PCR primers applied to ISSR fingerprinting of potato cultivars. Theoretical and Applied Genetics, 98(1), 107-112. https://doi.org/10.1007/s001220051046.

Reynoso, M. M., Chulze, S. N., Zeller, K. A., Torres, A. M., \& Leslie, J. F. (2009). Genetic structure of Fusarium verticillioides populations isolated from maize in Argentina.
European Journal of Plant Pathology, 123(2), 207-215. https://doi.org/10.1007/s10658-008-9359-1.

Rheeder, J. P., Marasas, W. F. O., Thiel, P. G., Sydenham, E. W., Shephard, G. S., \& Van Schalkwyk, D. J. (1992). Fusarium moniliforme and fumonisins in corn in relation to human esophageal cancer in Transkei. Phytopathology, 82, 353357. https://doi.org/10.1094/Phyto-82-353.

Rozas, J., Librado, P., Sánchez-Delbarrio, J.C., Messeguer, X., \& Rozas, R. (2009). DnaSP (version 5.10), Dna polymorphism analyses by the coalescent and other methods. Universitat de Barcelona, Spain.

Saharan, M. S. (2010). Detection of genetic variation among Fusarium spp. collected from wheat growing regions of India. Indian Phytopathology, 63(2), 149-153.

Scauflaire, J., Gourgue, M., \& Munaut, F. (2011). Fusarium temperatum sp. nov. from maize, an emergent species closely related to Fusarium subglutinans. Mycologia, 103(3), 586597. https://doi.org/10.3852/10-135.

Seifert, K. A., Aoki, T., Baayen, R. P., Brayford, D., Burgess, L. W., Chulze, S., Gams, W., Geiser, D., de Gruyter, J., Leslie, J. F., Logrieco, A., Marasas, W. F. O., Nirenberg, H. I., O'Donnell, K., Rheeder, J., Samuels, G. J., Summerell, B. A., Thrane, U., \& Waalwijk, C. (2003). The name Fusarium moniliforme should no longer be used. Mycological Research, 107(6), 643-644. https://doi.org/10.1017/S095375620323820X.

Shannon, C. E., \& Weaver, W. (1949). The mathematical theory of communication. Urbana, Illinois, USA: University of Illinois Press.

Singh, B. P., Saikia, R., Yadav, M., Singh, R., Chauhan, V. S., \& Arora, D. K. (2006). Molecular characterization of Fusarium oxysporum f. sp. ciceri causing wilt of chickpea. African Journal of Biotechnology, 5(6), 497-502.

Skorić, M., Šiler, B., Banjanac, T., Živković, J. N., Dmitrović, S., Mišić, D., \& Grubišić, D. (2012). The reproducibility of RAPD profiles: Effects of PCR components on RAPD analysis of four Centaurium species. Archives of Biological Sciences, 64(1), 191-199. https://doi.org/10.2298/ABS1201191S.

Steenkamp, E. T., Wingfield, B. D., Coutinho, T. A., Zeller, K. A., Wingfield, M. J., Marasas, W. F. O., \& Leslie, J. F. (2000). PCR-based identification of MAT-1 and MAT-2 in the Gibberella fujikuroi species complex. Applied Environmental Microbiology, 66, 4378-4382. https://doi. org/10.1128/AEM.66.10.4378-4382.2000.

Steenkamp, E. T., Wingfield, B. D., Desjardins, A. E., Marasas, W. F., \& Wingfield, M. J. (2002). Cryptic speciation in Fusarium subglutinans. Mycologia, 94(6), 1032-1043. https://doi.org/10.1080/15572536.2003.11833158.

Stępień, Ł., Koczyk, G., \& Waśkiewicz, A. (2013). Diversity of Fusarium species and mycotoxins contaminating pineapple. Journal of Applied Genetics, 54(3), 367-380. https://doi. org/10.1007/s13353-013-0146-0.

Tajima, F. (1989). Statistical method for testing the neutral mutation hypothesis by DNA polymorphism. Genetics, 123(3), 585-595.

Taylor, J. W., Geiser, D. M., Burt, A., \& Koufopanou, V. (1999). The evolutionary biology and population genetics underlying fungal strain typing. Clinical Microbiology Reviews, 12(1), 126-146. https://doi.org/10.1128/CMR.12.1.126.

Taylor, J. W., Jacobson, D. J., Kroken, S., Kasuga, T., Geiser, D. M., Hibbett, D. S., \& Fisher, M. C. (2000). Phylogenetic species recognition and species concepts in Fungi. Fungal Genetics and Biology, 31(1), 21-32. https://doi.org/10.1006/fgbi.2000.1228.

Tomczak, M., Wiśniewska, H., Kostecki, M., Chełkowski, J., \& Goliński, P. (2002). Deoxynivalenol, nivalenol and 
moniliformin in wheat samples with head blight (scab) symptoms in Poland (1998-2000). European Journal of Plant Pathology, 108(7), 625-630. https://doi.org/10.1007/97894-010-0001-7_3.

Vakalounakis, D. J., \& Fragkiadakis, G. A. (1999). Genetic diversity of Fusarium oxysporum isolates from cucumber: Differentiation by pathogenicity, vegetative compatibility and RAPD fingerprinting. Phytopathology, 89(2), 161-168. https://doi.org/10.1094/PHYTO.1999.89.2.161.

Van Hove, F., Waalwijk, C., Logrieco, A., Munaut, F., \& Moretti, A. (2011). Gibberella musae (Fusarium musae) sp. nov., a recently discovered species from banana is sister to $F$. verticillioides. Mycologia, 103(3), 570-585. https://doi.org/10.3852/10-038.

Viljoen, A., Marasas, W. F. O., Wingfield, M. J., \& Viljoen, C. D. (1997). Characterization of Fusarium subglutinans f. sp. pini causing root disease of Pinus patula seedlings in South Africa. Mycological Research, 101(4), 437-445. https://doi. org/10.1017/S0953756296002778.

Voss, K. A., Smith, G. W., \& Haschek, W. M. (2007). Fumonisins: Toxicokinetics, mechanism of action and toxicity. Animal Feed Science and Technology, 137(3-4), 299325. https://doi.org/10.1016/j.anifeedsci.2007.06.007.
Weising, K., Nybom, H., Pfenninger, M., Wolff, K., \& Kahl, G. (2005). DNA fingerprinting in plants: Principles, methods, and applications (p. 444). CRC press. https://doi. org/10.1201/9781420040043.

Wu, F. (2007). Measuring the economic impacts of Fusarium toxins in animal feeds. Animal Feed Science and Technology, 137(34), 363-374. https://doi.org/10.1016/j.anifeedsci.2007.06.010.

Yeh, F. C., Yang, R., \& Boyle, T. (1999). POPGENE version 1.32: Microsoft window-based freeware for population genetics analysis. Edmonton, Canada: University of Alberta.

Yli-Mattila, T., Paavanen-Huhtala, S., Bulat, S. A., Alekhina, I. A., \& Nirenberg, H. I. (2002). Molecular, morphological and phylogenetic analysis of the Fusarium avenaceum / $F$. arthrosporioides / F. tricinctum species complex-a polyphasic approach. Mycological Research, 106(6), 655-669. https://doi.org/10.1017/S0953756202006020.

Zargar, S. M., Farhat, S., Mahajan, R., Bhakhri, A., \& Sharma, A. (2016). Unraveling the efficiency of RAPD and SSR markers in diversity analysis and population structure estimation in common bean. Saudi Journal of Biological Sciences, 23(1), 139-149. https://doi.org/10.1016/j.sjbs.2014.11.011. 